\title{
Could cattle ranching and soybean cultivation be sustainable? A systematic review and a meta-analysis for the Amazon
}

\author{
Rafael da Silveira Bueno ${ }^{(1)}$, \\ Livia Marchetti ${ }^{(2)}$, \\ Claudia Cocozza ${ }^{(2)}$, \\ Marco Marchetti ${ }^{(3)}$, \\ Fabio Salbitano ${ }^{(2)}$
}

\section{Introduction}

Tropical forests harbor most of global terrestrial biodiversity and provide essential ecosystem services (ES), such as carbon sequestration (Sullivan et al. 2017), flood and drought control (Marengo 2006), influence on pluviometric regime (FAO/CIFOR 2019) with resulting effects on climate at the

\begin{abstract}
Tropical forests are being destroyed to make space for agricultural activities with the assumption that they are required to feed the growing global population. Consequently, more sustainable practices are needed to guarantee food security and environmental protection of highly threatened natural biodiversity hotspots like the Amazon rainforest. Cattle ranching and soybean cultivation are by far the greater drivers of land use change and deforestation in the Amazon region. We performed a systematic review of papers related to these two main drivers and a meta-analysis on the effects of sustainable practices on different ecosystem services. The results of the review highlight a large concern about the negative impacts of cattle ranching and soybean crops on the ecosystem dynamics and functionality of the Amazon biome, in addition to the clear relationship with deforestation. Another relevant finding is the large gap in empirical research concerning the effects of sustainable practices on different ecosystem services. Such a gap is evident since only 13 studies from the initial database met the requirements for a meta-analysis. Of the 171 comparisons between the ecosystem services provided in conventional land-uses and those adopting sustainable practices, the overall model indicated a non-significant effect, although the results were heterogeneous. Crop yield and herbage biomass were negatively affected, while livestock productivity, soil organic carbon, soil fertility and woody biomass were positively affected. Also, the six sustainable practices evaluated showed different outcomes, from a predominance of positive effects in silvopastoral systems, to a predominance of negative effects on agrosilvicultural systems. Our systematic review and meta-analysis indicate that cattle ranching and soybean cultivation can indeed be conducted in a more sustainable way, enhancing the provision of ecosystem services while avoiding deforestation. In turn, our results also highlight the lack of empirical data and the need to standardize the methodologies used to deeply assess the effects of such practices. In conclusion, we suggest a way to advance research into the real effects of sustainable practices aimed at reducing the negative impacts of cattle ranching and soybean crops in the Amazon.
\end{abstract}

Keywords: Tropical Forest, Agroforestry, Ecosystem Services, Silvopastoral Systems, Sustainable Practices, Cattle, Soybean

global level (Lovejoy \& Nobre 2019). Currently, the major pressure on native global forests burdens the tropical region, mainly in the Amazon biome (Marchetti 2005), where high rates of forest losses are often related to two main indirect factors: urban growth (rural-urban migration, urban food market) within countries (DeFries et al.
(1) Department of Agriculture, Food and Forest Sciences (SAAF), University of Palermo (Italy); (2) Department of Agriculture, Food, Environment and Forestry (DAGRI), University of Florence (Italy); (3) Lab. of Global Ecology, Department of Biosciences and Territory, University of Molise, Pesche, IS (Italy)

@ Livia Marchetti (livia.marchetti@unifi.it)

Received: Feb 09, 2021 - Accepted: Apr 12, 2021

Citation: Da Silveira Bueno R, Marchetti L, Cocozza C, Marchetti M, Salbitano F (2021). Could cattle ranching and soybean cultivation be sustainable? A systematic review and a meta-analysis for the Amazon. iForest 14: 285-298. - doi: 10.3832/ifor3779-014 [online 2021-06-08]

Communicated by: Marco Borghetti
2010) and growth of agricultural exports to other countries (Henders et al. 2015, Pettenella \& Masiero 2020). Changes in dietary preferences of the growing global population and the consequent increasing food demand determine an unprecedented need for agricultural products, which, in turn, drives deforestation, land degradation and overall loss of biodiversity (Kehoe et al. 2017, FAO/UNEP 2020). This is even more evident when crop and livestock management is not sustainable and when the expansion of the agriculture frontier causes conflicts with detrimental effects on natural forests. The production of two commodities is pinpointed as the main driver of Amazon deforestation: beef cattle (Barona et al. 2010) and soybean cultivation (Fearnside 2001, Domingues \& Bermann 2012, Gollnow et al. 2018, Celidonio et al. 2019).

Sustainable agricultural practices are posited as the main alternative to counteract land degradation and deforestation while 
producing food resources. These practices in the Amazon include different types of agro-silvopastoral systems, agroforestry, crop rotation and pasture improvement (Cerri et al. 2005, Murgueitio et al. 2011, Martorano et al. 2016, Soares et al. 2020).

This paper has the overall objective to review the available literature on the adoption of sustainable practices (SP) in cattle ranching and soybean cultivation in the Amazon region. Initially, this will paint a broad picture of the diversity, typologies and geographical distribution of such practices and, then, enables a meta-analysis to calculate the effects of such practices on the ES. The aim is to increase the awareness of people and the scientific community about the existence of alternatives to the conventional and often unsustainable agricultural model, as developed in the last decades in the Amazon region, as well as to encourage the subsidizing of SP by public policies and initiatives. The above-mentioned need emerges as a response to climate change and biodiversity crises and, in parallel, the application of new pathways in agriculture and food systems are a stronger concern in the post Covid-19 scenario, where preventive sustainable approaches are expected to contribute to reducing the risk of new epidemic diseases (Dobson et al. 2020, Galimberti et al. 2020).

\section{Materials and methods}

This paper has been based on an extensive literature review followed by (i) a review analysis and (ii) a meta-analysis. The literature search was performed on indexed documents within the Scopus ${ }^{\circledast}$ platform based on a progressive combination of keywords in the string "Title, abstract and keywords", then refined by "Keywords", on 3 and 4 September 2020. The search included research articles, reviews, conference papers and book chapters published in English, French, Portuguese and Spanish from 1989 to 2020, that were focused on the Amazon region. The following keywords have been used and combined with the keyword "Amazon" or "Amazon region": "sustainable cattle breeding", "sustainable cattle farming", "sustainable livestock", "sustainable beef", "integrated crop-livestock", "sustainable intensification", "silvopastoral systems", "sustainable soy", "sustainable soybean", "soybean sustainability", "soy zero deforestation". The results of the first phase of literature search consisted of a large number of papers, so the second step of selection was done by filtering the papers according to the inclusion criteria of SP (sustainable management, silvopastoral systems and agroforestry) and sectoral policies (commodity chains and certification policies). The final database included 274 papers: 167 for cattle and 107 for soybean. We checked the full text of $88 \%$ of the available papers. The documents without available full text (the remaining 12\%) were classified by using the abstracts so as to an- notate full reference, year of publication, research location, and self-reported keywords (SRK from here on).

The review analysis was performed through three subsequent steps.

1. Qualitative evaluation to discriminate the general characteristics of papers and their contents. The papers were grouped in 4 "topic" categories (TAA: Topic Assigned by the Authors): sustainable practices, sustainable management, certification policies, supply chain initiatives. We define as "sustainable practices" the concrete actions and experiments reported by the papers, while "sustainable management" refers to papers addressing general topics oriented to identify processes and procedures of managing more than the specific actions undertaken.

2. SRK were extracted and those addressing the same concept were grouped to obtain a major conceptual understanding and to avoid excessive dispersion of terminology. We set a threshold of 6 keywords with converging meaning to generate a SKR group.

3. The content of papers addressing SP for both drivers has been analyzed, with both quantitative and qualitative approach, in order to check the data suitability towards performing a meta-analysis.

The first search step for papers suitable for the meta-analysis resulted in 144 papers referring to the following topics: "integrated crop-livestock-forestry systems" (cattle), "livestock sustainable management" (cattle) and "integrated production systems" (soybean). The papers referring to the other topic categories (policies, supply chain initiatives) were excluded because the data reported were not consistent to apply the meta-analytic process. Afterward, we selected all papers related to the Amazon region (93 papers). The next selection excluded papers not including quantitative primary data (i.e., authors direct measurements in the field) so reducing the database to 40 papers. Later on, papers reporting extractable quantitative data suitable for performing the meta-analysis (mean values, standard deviation and sample size) were selected. The final selection consisted of 13 papers, comprising 6 SP (agropastoral, agrosilvicultural, agrosilvopastoral, crop rotation, pasture improvement and silvopastoral - see Tab. S1 in Supplementary material), whose ES were compared against conventional systems, defined and identified exclusively based on the information present in analyzed papers, with data usually shown as a specific column in a table. The studies usually refer to monoculture (e.g., soybean) or a pastureland without trees or crop rotation as a conventional system. Due to a high heterogeneity of the ES variables assessed in these studies, we reclassified the reported data according to 6 categories so as to allow a more robust comparison: animal pro- ductivity, herbage biomass, soil organic carbon (SOC), soil fertility, woody biomass and crop yield. Most studies compared more than one ES and more than one SP type. Furthermore, the timing of sampling (e.g., different years), the type of indicators, and the different depths in soil sampling are variables expressed by the datasets reported in the papers. We considered each comparison (i.e., a specific ES variable in a specific type of conventional system against a specific type of SP) inside the same study as an independent observation. As a complementary explanatory variable, we also extracted mean annual precipitation and temperature from the studies, and in the few cases in which they were not specified we used study location to get information from other published studies in the same area. Of these $13 \mathrm{pa}$ pers, 7 presented data also comparing the SP systems against natural vegetation. The natural vegetation status or physiognomy definition varied across studies and was not always clear, but it comprehended mainly primary and late-successional forests (Tab. S1). With these 7 papers we performed a separate analysis to calculate the effect sizes of natural vegetation.

To investigate the effects of the adoption of SP on ES, the effect size was derived from the response ratio, obtained by subtracting the specific value of an ES variable (e.g., crop yield) in the reference system (e.g., monoculture cropland) from the value obtained in the SP, both log-transformed. This procedure is widely used in meta-analyses where the source data is heterogeneous (Torralba et al. 2016, De Stefano \& Jacobson 2018). Generally, a positive ratio indicates a positive effect of the SP, while negative values indicate negative influence. When this was not true for some specific variable, the signal was inverted to standardize the interpretation. Mean effect sizes, $Z$ and $p$ values and $95 \%$ confidence intervals were obtained by random effect models, and heterogeneity, both overall and within groups, was checked using a Q-test. We first performed an overall random effect model with all data, and then separated models for each variable group, SP type and their combinations. Study bias was checked with fail safe analysis, where a number larger than the number of studies indicates lack of bias. All analyses were performed using the "metafor" package in $\mathrm{R}$ ver. 3.6.1 ( $\mathrm{R}$ Core Team 2019).

\section{Results}

Results concerning the research location and the keywords analysis are presented first, for a better understanding. The results of the meta-analysis are presented immediately after, and in this case the evaluation has been performed jointly for the two drivers.

With regards to cattle ranching, $167 \mathrm{pa}$ pers have been collected. Most of them were directly related to the Amazon region 


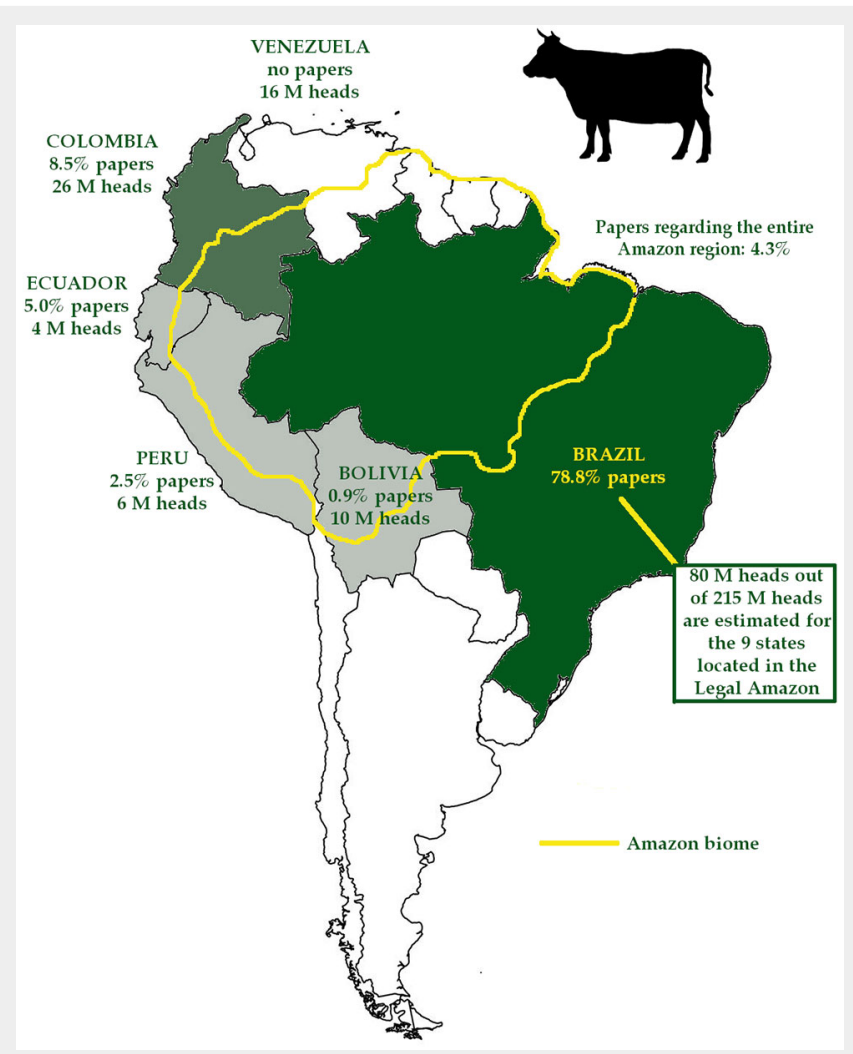

Fig. 1 - Number of livestock and proportion of papers in the Amazon region by country. Author's elaboration based on FAOSTAT data (2019) and IBGE (Instituto Brasileiro de Geografia e Estatistica) - Censo Agropecuário 2017. Guyana, French Guyana and Suriname have not been considered for this figure, since data were not significant.

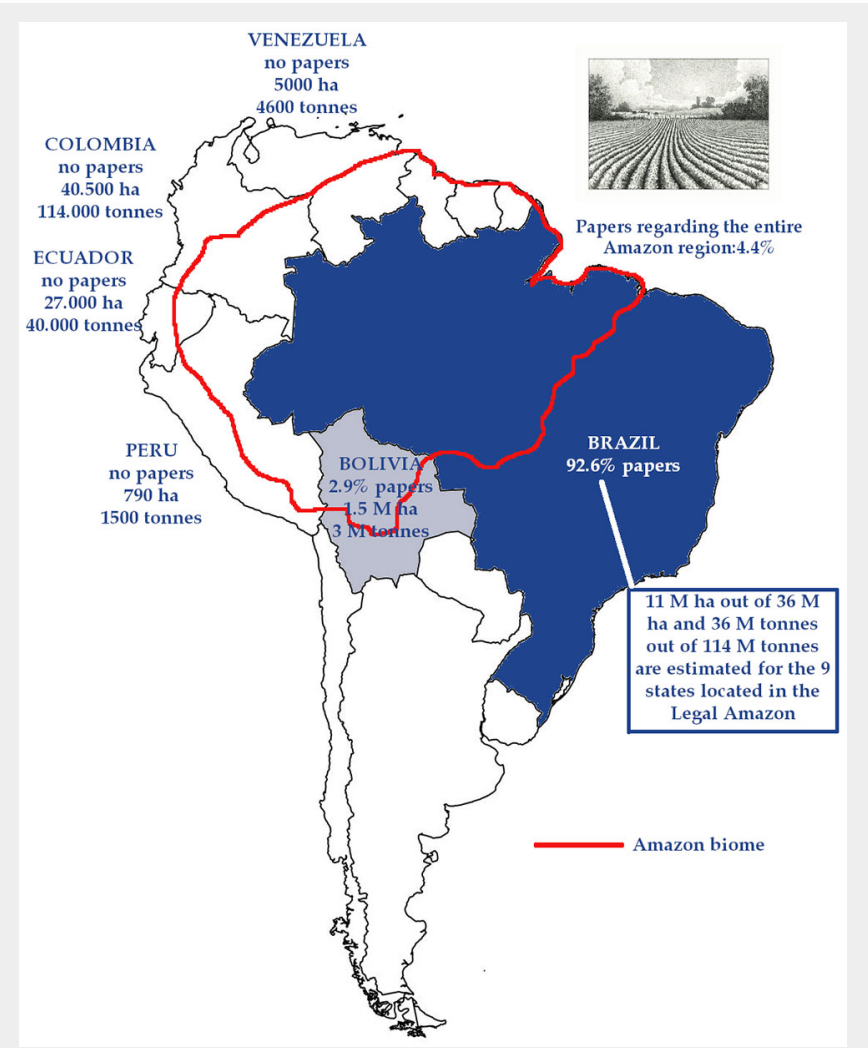

Fig. 2 - Soybean harvested area (ha), production (tonnes) and proportion of papers in the Amazon region by country. Author's elaboration based on FAOSTAT data (2019) and IBGE (Instituto Brasileiro de Geografia e Estatistica) - Censo Agropecuário 2017. Guyana, French Guyana and Suriname have not been considered for this figure, since data were not significant.
(70.7\%), with a different distribution between countries (Fig. 1).

The other papers considered valid for the analysis (39.3\%) regarded Latin American countries outside the Amazon basin and a global view about commodity chains and international policies and trade.

With regards to soybean, 107 papers have been collected. Most of them were directly related to the Amazon region (63.5\%), predominantly in Brazil and to a lesser extent in Bolivia (Fig. 2).

The other papers considered valid for the analysis (36.5\%) regarded the Amazon region in a broader sense, mainly related to commodity chains and international policies and trade, and some examples of SP carried out in other Latin American regions, outside the Amazon basin.

In the selected studies about cattle ranching, the TAA with the highest number of studies was "livestock sustainable management" (46\%), which includes a general approach to sustainability in the cattle sector, including the so called "sustainable intensification" (SI), followed by the topic "integrated crop-livestock-forestry systems" (28\%), concerning mainly silvopastoral systems. Differently from cattle, the predominant categories of TAA for soybean regard papers related to policies (48\%) and supply chain initiatives (39\%). Papers dealing with sustainable agricultural practices represent only the $13 \%$ of the total, and mainly refer to crop rotation.

Regarding the most abundant SRK $(\mathrm{N}>6)$ for cattle ranching, deforestation, silvopastoral systems and sustainability were the most cited, indicating that both the negative and positive aspects of cattle ranching and soybean cultivation were assessed in the studies (Fig. 3). For soybean, SRK referring to deforestation and land use change are largely predominant, and a lack of SRK addressing SP was noticed (Fig. 3).

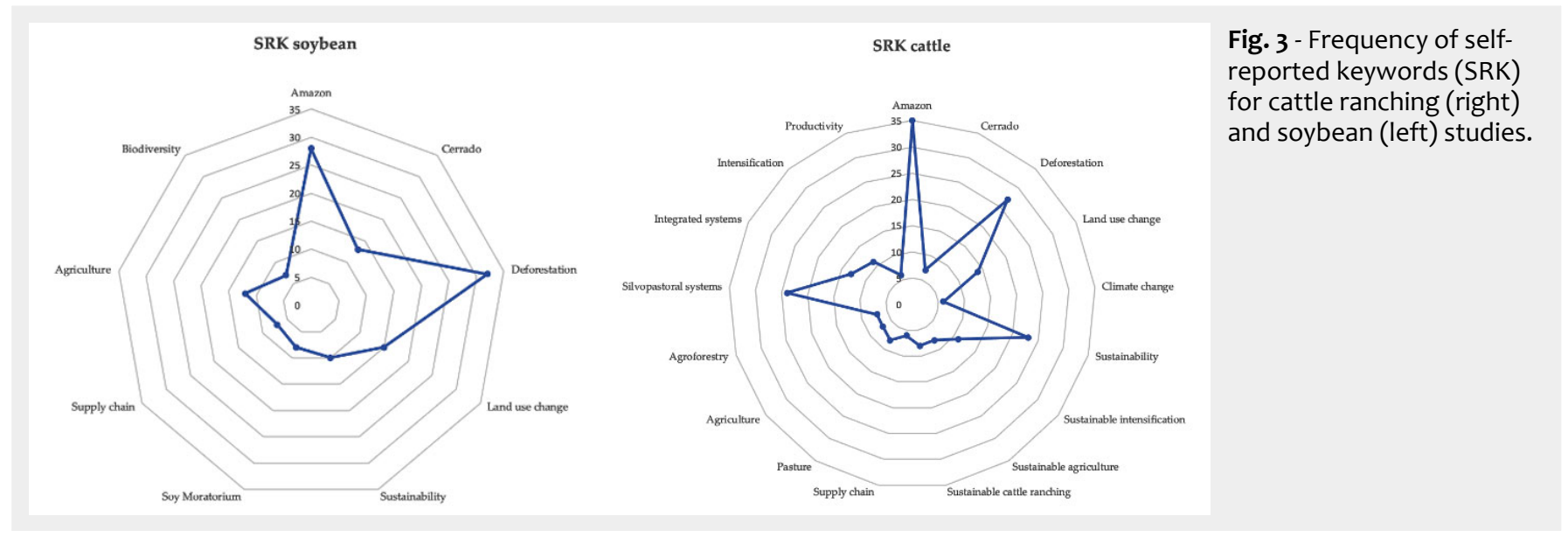


Tab. 1 - Sustainable practices in cattle-ranching and their role in improving ecosystem services. Qualitative aspect as self-reported by the authors of the reviewed papers or re-assigned during the analysis. (*): According to MEA (2005): (S) Support; (P) Provisioning; (R) Regulating; (C) Cultural.

\begin{tabular}{lll}
\hline Proposed practice & $\begin{array}{l}\text { Ecosystem services improvements*I } \\
\text { environmental positive effects (self-reported) }\end{array}$ & References \\
\hline $\begin{array}{lll}\text { Eucalyptus + soybean/corn } \\
\text { intercropped with pasture in the } \\
\text { interrow }\end{array}$ & $\begin{array}{l}\text { S: increase of SOM; increased soil fertility and porosity; } \\
\text { P: improved forage and meat yield; R: mitigation of } \\
\text { tropical heat; C: alternatives to increase property } \\
\text { revenues }\end{array}$ & $\begin{array}{l}\text { Domiciano et al. (2020), } \\
\text { et al. (2019), Moreira et al. } \\
\text { (2018) }\end{array}$ \\
\hline Eucalyptus, pine, teak, balsa + & S: increase of soil porosity & Oliveira et al. (2017)
\end{tabular}
crops + livestock grazing

Trees, maize, grass, forage legumes and kudzu + natural forest regeneration + livestock grazing

Trees (for timber, firewood and fruit) + forages + livestock grazing

Eucalyptus + livestock grazing (palisadegrass)

African mahogany, eucalyptus and paricá (native species) + livestock

African mahogany and cumaru + livestock grazing

Teak + livestock grazing

ISPSs (Intensive Silvopastoral Systems) - high-density cultivation of fodder shrubs with improved tropical grasses and trees

Leucaena leucocephala + livestock grazing

Mixed forage bank from different tree species

Different tree species in rows + improved pasture with fodder bank Native trees and shrubs + rotational grazing systems

Crop-livestock integration: crop rotation (soybean/corn/cotton) + livestock grazing

Rotational grazing

Pasture improvement (fertilization, S: increased pasture productivity; P: use of forage irrigation, re-seeding)

Introduction of forage legumes

Feedlot based intensification

S: enhanced species diversity; complete use of resources; pest protection; nutrients recycling; maintenance of soil structure; $\mathrm{P}$ : production diversification; C: adoptability for smallholders S: diversity of tree species and forage species; multiple purpose of trees

$\mathrm{P}$ : improved forage-based system; greater herbage accumulation; R: enhanced microclimate (mitigation) mitigation of cattle enteric emissions; increased soil C sequestration

P: satisfactory tree performances; production diversification; C: alternatives to increase property revenues

$\mathrm{P}$ : production diversification; $\mathrm{R}$ : increased soil C sequestration

$\mathrm{P}$ : high quality products; production diversification; $\mathrm{C}$ credits; R: mitigation of erosion and desertification

S: enhanced biodiversity; soil conservation; $\mathrm{P}$ : production diversification; improved tree cover; R: climate change mitigation; increased soil $\mathrm{C}$ sequestration; water regulation; $\mathrm{C}$ : suitable for all farm scales, landscape restoration

$\mathrm{S}$ : enhanced biodiversity; $\mathrm{N}$ fixation (soil improvement); $\mathrm{P}$ : improved fodder resources; R: soil $\mathrm{C}$ sequestration; climate change mitigation

R: climate change mitigation; increased soil C sequestration; C: improved socio-economic conditions of farmers

R: GHG emissions reduction; increased soil C sequestration

S: biodiversity conservation; R: water regulation, improved $\mathrm{C}$ stocks

S: soil conservation and improvement; $\mathrm{P}$ : higher annual net present value; R: C sequestration; reduction of soil greenhouse gases; lower GHG emissions; mitigation of climate change;

$\mathrm{R}$ : recovery of degraded pasture; low energy and water use; C: alternatives to increase property revenues legumes; R: recovery of degraded pasture; C: low cost per ha

S: soil conservation; soil properties improvement; functional biodiversity; R: water balance; mitigation of global warming and of groundwater contamination; rehabilitation of degraded land; C: saving of fossil energy al. (2006)

Loker (1994)

Pizarro et al. (2020)

Gomes et al. (2020), Domiciano et al. (2020), De Carvalho et al. (2019), De Oliveira Resende et al. (2019), Oliveira et al. (2018)

Silva \& Schwartz (2019)

Silva et al. (2018)

Ansolin et al. (2020)

Murgueitio et al. (2013), Calle et al. (2012), Murgueitio et al. (2011)

Chará et al. (2019), Murgueitio et al. (2011)

Amézquita et al. (2005)

Landholm et al. (2019)

Murgueitio et al. (2011), Lerner et al. (2015)

Soares et al. (2020), Dos Reis et al. (2019), Carvalho et al. (2018) Gil et al. (2018), Carvalho et al. (2014)

Pedrosa et al. (2019), zu Ermgassen et al. (2018), Gil et al. (2018)

Pedrosa et al. (2019), Latawiec et al. (2014)

Schultze-Kraft (2018), zu Ermgassen et al. (2018), DubeuxJunior et al. (2017), Hohnwald et $\mathrm{R}$ : decrease of on-property deforestation

Vale et al. (2019)
In Tab. 1, a summary of SP for cattle ranching extracted from the analyzed papers, and their self-reported contributions to ES improvements are presented. The table is divided in two parts. The first part includes agroforestry, agrosilvopastoral and silvopastoral systems, which comprise a va- riety of combinations between shrubs and trees, forage plants (grasses and leguminous herbs) and livestock. All of these practices are indicated by the authors as strategies to achieve a more sustainable livestock production and to limit its pressure on tropical forests. The second part reports on the SI approach, intended as the implementation of practices oriented to increase crop and fodder production per area thanks to a more efficient use of inputs, so as to reduce pressure and impacts on land. 
Tab. 2 - Summary of the meta-analysis. Q represents the coefficient of the Q-test for heterogeneity and P its significance level. SP1 dataset included conventional cropland and pastureland as comparator; SP2 dataset included natural vegetation. $(*): p<0.05 ;(* *)$ : $\mathrm{p}<0.01 ;(* * *): p<0.001 ;(n s):$ non significant.

\begin{tabular}{|c|c|c|c|c|c|c|c|c|c|}
\hline Dataset & $\begin{array}{l}\text { Moderator } \\
(\mathrm{Q}, \mathrm{P})\end{array}$ & Ecosystem service & Effect size & SE & Z & $\mathrm{p}$ & $\begin{array}{l}95 \% \mathrm{Cl} \\
\text { lower }\end{array}$ & $\begin{array}{l}95 \% \mathrm{Cl} \\
\text { upper }\end{array}$ & $\mathbf{N}$ \\
\hline \multirow[t]{13}{*}{ SP1 } & Overall RE model & - & -0.025 & 0.017 & -1.429 & ns & -0.058 & 0.009 & 171 \\
\hline & \multirow{6}{*}{$\begin{array}{l}\text { Ecosystem service } \\
(82.61 ;<0.001)\end{array}$} & Crop yield & -0.192 & 0.028 & -6.958 & $* * *$ & -0.246 & -0.138 & 35 \\
\hline & & Herbage biomass & -0.152 & 0.03 & -5.101 & $* * *$ & -0.211 & -0.094 & 29 \\
\hline & & Livestock productivity & 0.194 & 0.096 & 2.027 & * & 0.006 & 0.381 & 9 \\
\hline & & SOC & 0.084 & 0.028 & 2.971 & $* *$ & 0.029 & 0.14 & 49 \\
\hline & & Soil fertility & 0.029 & 0.032 & 0.922 & ns & -0.033 & 0.091 & 28 \\
\hline & & Woody biomass & 0.103 & 0.044 & 2.319 & $*$ & 0.016 & 0.19 & 21 \\
\hline & \multirow{6}{*}{$\begin{array}{l}\text { SP type } \\
(21.24 ;<0.001)\end{array}$} & Agropastoral & -0.088 & 0.048 & -1.822 & ns & -0.183 & 0.007 & 14 \\
\hline & & Agrosilvicultural & -0.235 & 0.064 & -3.639 & $* * *$ & -0.361 & -0.108 & 13 \\
\hline & & Agrosilvopastoral & -0.085 & 0.046 & -1.855 & ns & -0.175 & 0.005 & 30 \\
\hline & & Crop rotation & 0.066 & 0.066 & 1.006 & ns & -0.063 & 0.195 & 9 \\
\hline & & Pasture improvement & 0.063 & 0.037 & 1.72 & ns & -0.009 & 0.135 & 32 \\
\hline & & Silvopastoral & -0.017 & 0.024 & -0.684 & ns & -0.064 & 0.031 & 73 \\
\hline \multirow[t]{8}{*}{ SP2 } & Overall RE model & - & 0.008 & 0.022 & 0.369 & ns & -0.036 & 0.052 & 89 \\
\hline & \multirow{4}{*}{$\begin{array}{l}\text { Ecosystem service } \\
(2.39 ; 0.495)\end{array}$} & Herbage biomass & 0.019 & 0.225 & 0.086 & ns & -0.421 & 0.46 & 5 \\
\hline & & SOC & 0.011 & 0.036 & 0.318 & ns & -0.058 & 0.081 & 49 \\
\hline & & Soil fertility & 0.049 & 0.027 & 1.784 & ns & -0.005 & 0.102 & 20 \\
\hline & & Woody biomass & -0.058 & 0.02 & -2.954 & $* *$ & -0.096 & -0.019 & 15 \\
\hline & \multirow{3}{*}{$\begin{array}{l}\text { SP type } \\
(0.75 ; 0.685)\end{array}$} & Crop rotation & -0.046 & 0.04 & -1.144 & ns & -0.124 & 0.033 & 9 \\
\hline & & Pasture improvement & 0.014 & 0.052 & 0.272 & ns & -0.088 & 0.116 & 32 \\
\hline & & Silvopastoral & 0.013 & 0.022 & 0.587 & ns & -0.03 & 0.056 & 48 \\
\hline
\end{tabular}

Tab. 3 - Summary of the meta-analysis. $(*): p<0.05 ;(* *): p<0.01 ;(* * *): p<0.001 ;(n s)$ : non significant.

\begin{tabular}{|c|c|c|c|c|c|c|c|c|c|}
\hline Dataset & $\begin{array}{l}\text { Sustainable } \\
\text { practice }\end{array}$ & Ecosystem service & Effect size & SE & Z & $\mathrm{p}$ & $\begin{array}{l}95 \% \mathrm{Cl} \\
\text { lower }\end{array}$ & $\begin{array}{l}95 \% \mathrm{Cl} \\
\text { upper }\end{array}$ & N \\
\hline \multirow[t]{17}{*}{ SP1 } & \multirow[t]{3}{*}{ Agropastoral } & Crop yield & -0.166 & 0.054 & -3.078 & $* *$ & -0.271 & -0.06 & 8 \\
\hline & & Herbage biomass & 0.076 & 0.042 & 1.791 & ns & -0.007 & 0.159 & 3 \\
\hline & & Livestock productivity & 0.112 & 0.166 & 0.67 & ns & -0.215 & 0.438 & 3 \\
\hline & \multirow[t]{2}{*}{ Agrosilvocultural } & Crop yield & -0.233 & 0.065 & -3.563 & $* * *$ & -0.361 & -0.105 & 9 \\
\hline & & Soil fertility & -0.313 & 0.498 & -0.629 & ns & -1.288 & 0.662 & 4 \\
\hline & \multirow[t]{4}{*}{ Agrosilvopastoral } & Crop yield & -0.178 & 0.035 & -5.063 & $* * *$ & -0.247 & -0.109 & 18 \\
\hline & & Herbage biomass & -0.031 & 0.039 & -0.778 & ns & -0.108 & 0.047 & 3 \\
\hline & & Livestock productivity & 0.271 & 0.178 & 1.523 & ns & -0.078 & 0.619 & 3 \\
\hline & & Woody biomass & 0.14 & 0.148 & 0.945 & ns & -0.15 & 0.43 & 6 \\
\hline & \multirow[t]{2}{*}{ Crop rotation } & SOC & 0.153 & 0.053 & 2.879 & $* *$ & 0.049 & 0.257 & 6 \\
\hline & & Soil fertility & -0.105 & 0.129 & -0.815 & ns & -0.357 & 0.147 & 3 \\
\hline & Pasture improvement & SOC & 0.063 & 0.037 & 1.72 & ns & -0.009 & 0.135 & 32 \\
\hline & \multirow[t]{5}{*}{ Silvopastoral } & Herbage biomass & -0.195 & 0.029 & -6.643 & *** & -0.253 & -0.138 & 23 \\
\hline & & Livestock productivity & 0.206 & 0.154 & 1.334 & ns & -0.097 & 0.508 & 3 \\
\hline & & SOC & 0.134 & 0.049 & 2.769 & $* *$ & 0.039 & 0.23 & 11 \\
\hline & & Soil fertility & 0.055 & 0.029 & 1.903 & ns & -0.002 & 0.111 & 21 \\
\hline & & Woody biomass & 0.1 & 0.03 & 3.359 & *** & 0.041 & 0.158 & 15 \\
\hline \multirow[t]{7}{*}{ SP2 } & \multirow[t]{2}{*}{ Crop rotation } & SOC & -0.104 & 0.04 & -2.612 & $* *$ & -0.182 & -0.026 & 6 \\
\hline & & Soil fertility & 0.067 & 0.041 & 1.629 & ns & -0.014 & 0.147 & 3 \\
\hline & Pasture improvement & SOC & 0.014 & 0.052 & 0.272 & ns & -0.088 & 0.116 & 32 \\
\hline & \multirow[t]{4}{*}{ Silvopastoral } & Herbage biomass & 0.019 & 0.225 & 0.086 & ns & -0.421 & 0.46 & 5 \\
\hline & & SOC & 0.066 & 0.039 & 1.698 & ns & -0.01 & 0.142 & 11 \\
\hline & & Soil fertility & 0.047 & 0.032 & 1.448 & ns & -0.017 & 0.11 & 17 \\
\hline & & Woody biomass & -0.058 & 0.02 & -2.954 & ** & -0.096 & -0.019 & 15 \\
\hline
\end{tabular}


Fig. 4 - Mean effect size and confidence interval of SP compared to natural vegetation and cropland/pastureland. Mean effect size (dots) and $95 \%$ confidence interval

(lines) of SP on the ES categories in comparison with conventional cropland and pastureland (upper panel) and natural vegetation (lower panel). 95\% Cl lines that do not over-

lap the dashed line are significant.

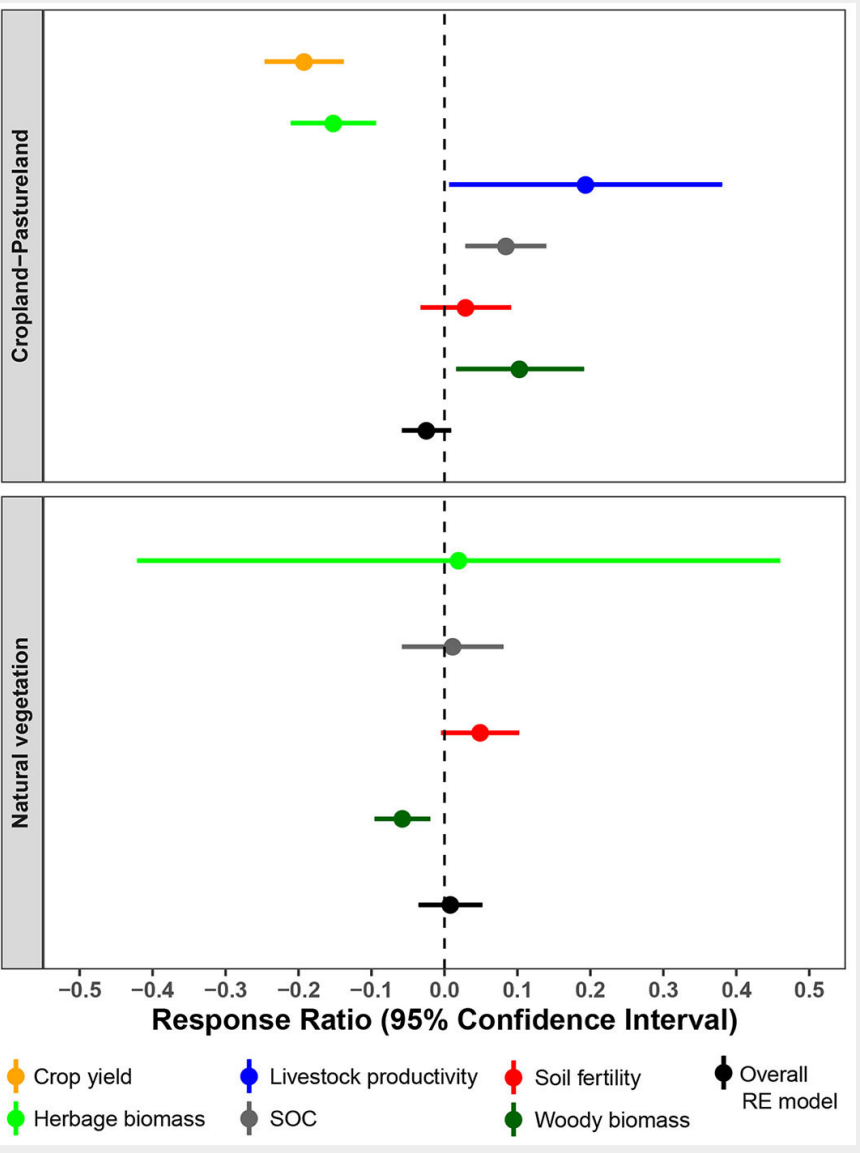

Meta-analysis on sustainable practices From our initial database, only 13 publications comparing 6 types of SP against cropland and pasturelands met the requirements to be included in the meta-analysis, representing a total of 171 comparisons of ES variables between conventional systems and sustainable practices derived from the papers (hereafter SP1 dataset Tab. 2). Although a minimum of 2 studies are recommended for a meta-analysis (Valentine et al. 2010), we decided to include crop yield (only one study) due to its economical relevance in the Amazon, and also because it was evaluated in 3 different SP systems for a total of 35 comparisons. Six of the 13 publications also compared the SP against natural vegetation, for a total of 89 comparisons (hereafter SP2 dataset). In both $\mathrm{SP} 1$ and $\mathrm{SP} 2$ datasets most comparisons were made against silvopastoral systems (42.9\% and $53.6 \%$, respectively), and soil organic carbon (SOC) was the most representative variable assessed (28.6\% and $55.1 \%$ of the comparisons, respectively).

The random effect model including all studies in the SP1 dataset indicated a slightly negative, albeit non-significant, mean response ratio (RR) of the ES in the areas adopting SP (mean effect size $=-0.024, p=$ 0.153 - Tab. 2, Fig. 4).

However, highly variable outcomes were found, as indicated by the significant het-

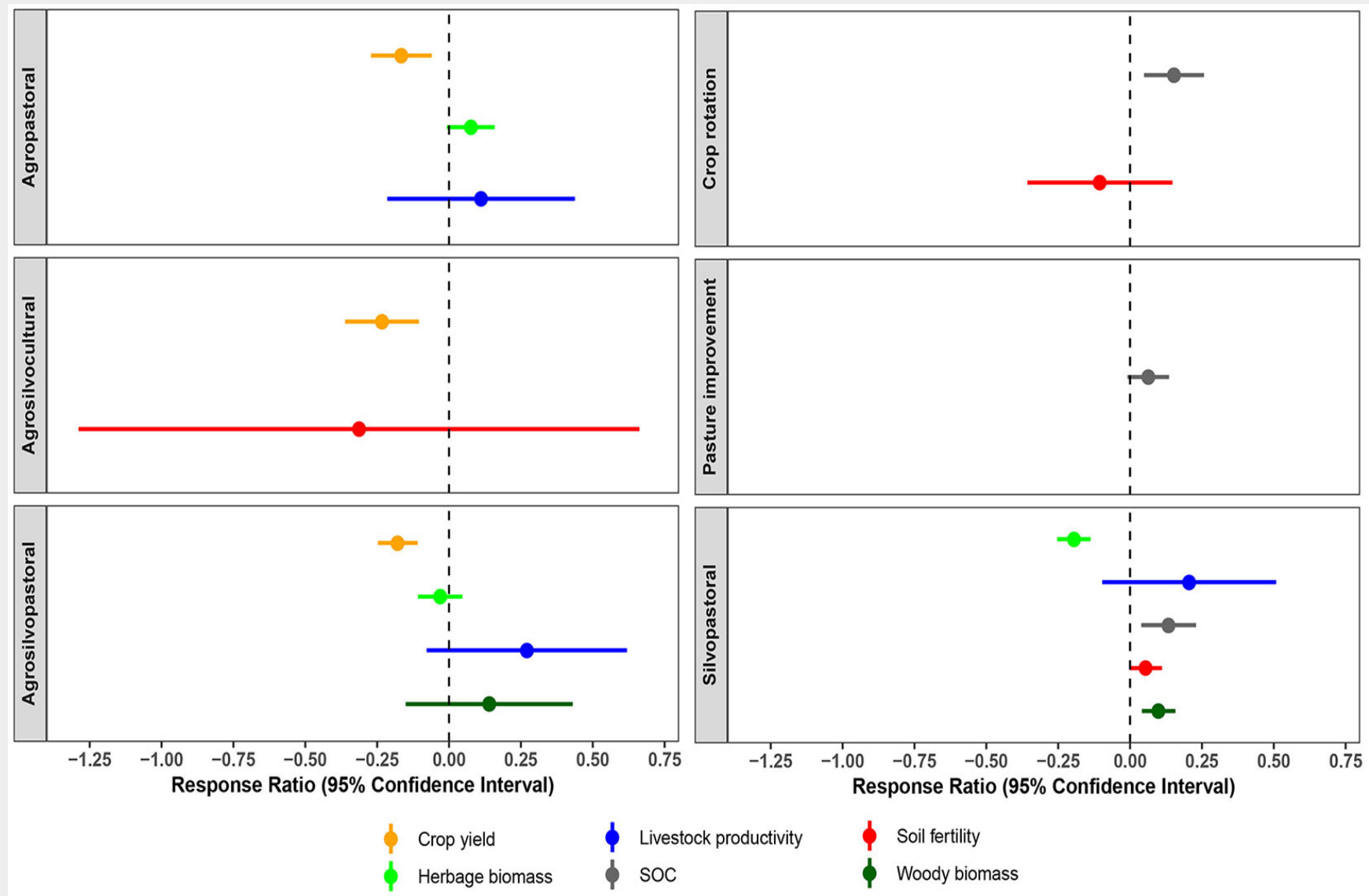

Fig. 5 - Mean effect size and confidence interval of SP in comparison with conventional cropland and pastureland. Mean effect size (dots) and 95\% confidence interval (lines) of SP on the ES categories in comparison with conventional cropland and pastureland. $95 \% \mathrm{Cl}$ lines that do not overlap the dashed lines are significant. 
erogeneity index $(\mathrm{Q}=9132, \mathrm{p}<0.001)$, although the fail safe analysis results showed no bias in the study $(\mathrm{N}=26136)$. The overall random effect model in the SP2 dataset indicated a slightly positive, albeit non-significant, mean response ratio (RR) of the ES in the areas adopting SP (mean effect size $=0.008, p=0.73-$ Tab. 2, Fig. 4), also with high and significant heterogeneity $(Q=909, p<0.001)$ but no sign of study bias (fail safe $\mathrm{N}=1133$ ).

Despite a positive trend, we found a marginal significant relationship between effect size and average annual rainfall ( $F=$ 3.50, $p=0.062$ ) but no relationship with temperature $(F=0.33, p=0.56$; see Fig. $\mathrm{S} 1$ and Fig. $\mathrm{S} 2$ in the Supplementary material).

\section{Comparison of ES and SP types}

In the SP1 dataset, the mean effect size of the random effect models for the ES was positive (0.018), with SOC, livestock productivity and woody biomass positively affected by SP, while herbage biomass and crop yield were negatively influenced. The coefficient for soil fertility was also positive, although no significant differences were detected (Tab. 2, Fig. 4). In the SP2 dataset, woody biomass was negatively affected by SP, while no significant differences were found for the other variables (Tab. 2, Fig. 4). In the overall random effect models of the SP1 for each SP, only the agrosilvicultural model was significant, with negative effect sizes on the ES (Tab. 2, Fig. 4).

\section{Comparison of ES by SP types}

In the SP1 dataset random effect models testing the influences of SP on each ecosystem service, 7 combinations were significant. Among the significant combinations, crop yield was the only service negatively affected in all comparisons, while livestock productivity, $\mathrm{SOC}$ and woody biomass were positively affected in all comparisons (Tab. 3, Fig. 5).

Herbage biomass and soil fertility in turn were both positively and negatively affected. Regarding the SP types, only agrosilvicultural systems presented negative effects on the ES evaluated (crop yield and soil fertility). In the SP2 dataset, only 2 combinations were significant, $\mathrm{SOC}$ on crop rotation and woody biomass on silvopastoral systems, both with negative effect sizes. The other variables present in more than one SP presented both positive and negative effects (Tab. 3, Fig. 6).

\section{Discussion}

The review highlights that studies addressing SP in cattle ranching and soybean cultivation in the Amazon region are by far prevailing in Brazil (78.8\% of total papers for cattle and $92.6 \%$ for soybean, respectively). This is firstly explained by the fact that almost $60 \%$ of the entire Amazon forest is located in Brazil. Secondly, the recent upturn in Amazon deforestation (Amigo 2020) has dramatically drawn attention

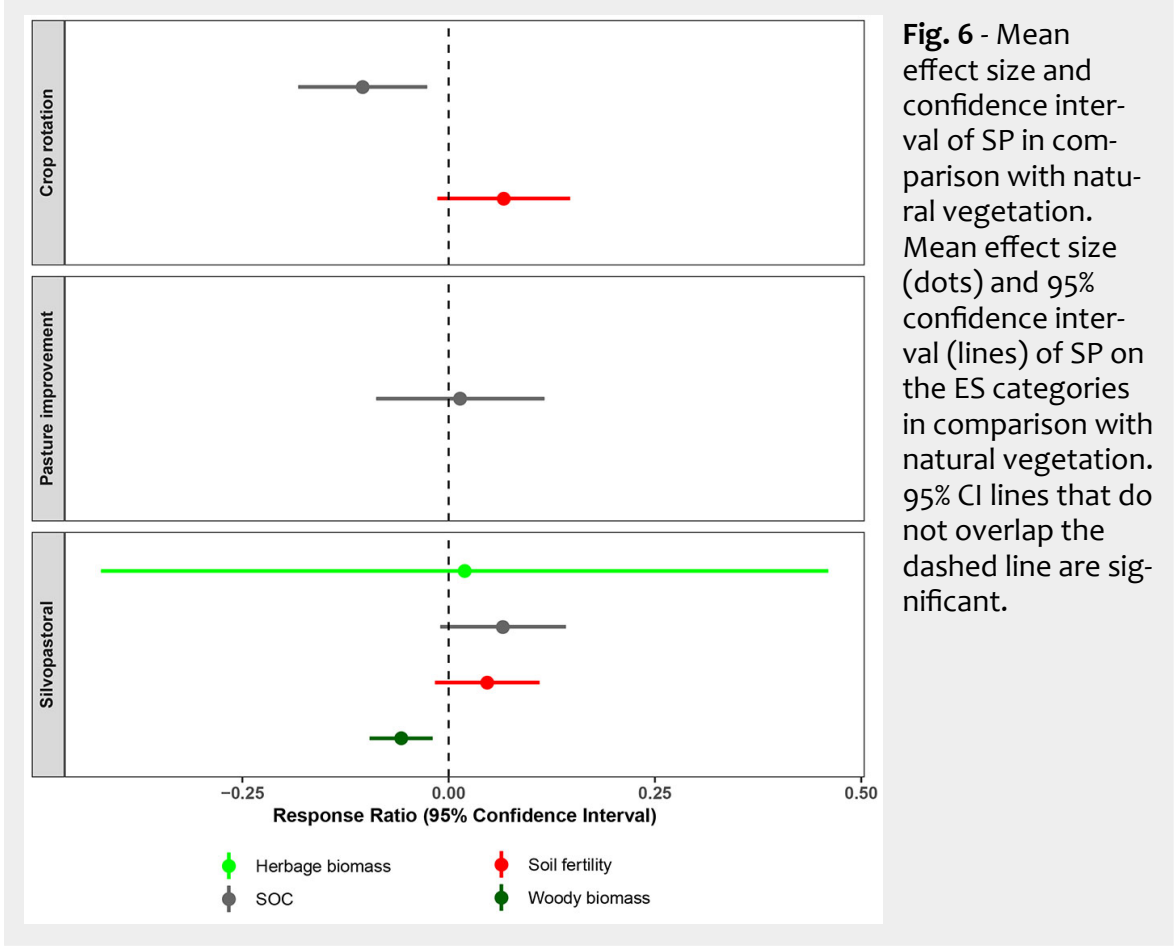

again to the impact of permanent land cover changes and environmental degradation in the Brazilian Amazon. A third key factor is that Brazil is by far the largest soybean and livestock producer and trader among countries within the Amazon region (Chung et al. 2020, Voora et al. 2020). Furthermore, as shown in Fig. 1 and Fig. 2, the geographical distribution of studies reflects quite well how the two drivers are actually spread within the region. The only exception regards cattle ranching in Venezuela: according to FAOSTAT (Fig. 1), it has the third livestock number among Amazon countries, but, regrettably, no studies about this country were found in the literature.

Concerning the geographical distribution of SP, Brazil dominates, confirming trends. An interesting outcome of SP-country relations is that studies found in Brazil show a clear pattern in proposing practices which apply to the large-scale/industrial model, that characterize the Brazilian territory. In fact, Eucalyptus spp. or timber rentable species are dominant as tree species in agroforestry and silvopastoral systems, while the enhancement of tree species diversity appears rare in the proposed systems. This is in contrast with SP proposed for the other Amazonian countries. For Colombia, Peru, and Ecuador the proposed SP regarding diversified and complex silvopasture practices, which can be applied also at the small-scale, include native tree species and nitrogen-fixing plants, and consider a natural succession-based approach. Interestingly, self-reported ES do not differ so much between countries and type of SP. This suggests to take into consideration trade-offs among such diverse practices (e.g., the frequently cited $C$ sequestration conservation).

\section{$\mathrm{SP}$ in cattle ranching and soybean cultivation}

The transformation of primary/secondary forest for agriculture, industrial legal/illegal logging, and pasture has been and is the main direct driver of tropical deforestation (Armenteras et al. 2019). Furthermore, a relevant part (the $50 \%$ of total pastures in Brazil, according to Dias-Filho 2015) of Amazon pasturelands is classified as "degraded" and, consequently, shows a substantial decrease in productivity. SP for cattle ranching should address primarily the restoration of the productive potential of already existing degraded pastures (Cerri et al. 2005, Montagnini 2008, Murgueitio et al. 2011, Calle et al. 2012, Montagnini et al. 2013, Hohnwald et al. 2015, Landholm et al. 2019, Carvalho et al. 2020). In this perspective, Strassburg et al. (2014) and Brandão et al. (2020) estimated that increasing efficiency and productivity of Brazil's grasslands and pasturelands could cover the curproducts and biofuels until 2040, without further conversion of natural ecosystems. As indicated by our review, different types of SP are available to contribute to pasture improvement and restoration.

The SI approach (Tab. 1) aims to achieve a best performing use of land in the livestock sector while restoring unproductive and degraded pastures. A first set of techniques includes rotational grazing (Gil et al. 2018, zu Ermgassen et al. 2018, Pedrosa et al. 2019), improved pasture diversification using forage legumes (Hohnwald et al. 2006, Dubeux-Junior et al. 2017, SchultzeKraft et al. 2018, zu Ermgassen et al. 2018), is often not correlated with biodiversity rent production of meat, crops, wood 
and crop rotation and crop-livestock integration (Gil et al. 2015, Dos Reis et al. 2019, Soares et al. 2020). A second SI approach includes pasture improvement through fertilization, irrigation and/or re-seeding, cattle nutritional feed supplements, improved animal breeding, and feed-lot based intensification with confinement. The review revealed contradictions and trade-offs in SI application. The idea of SI proposes to produce more on increasingly smaller land. This could slow deforestation and free space for other food crops. However, controversial examples are reported: (i) the risk of "rebound effects", related to intensification in agricultural frontiers, which can itself induce agricultural expansion by making the activity more rentable and attractive (Latawiec et al. 2014, zu Ermgassen et al. 2018); (ii) the connection between intensification and infrastructure development (road construction, slaughterhouses, etc.) which can increase deforestation (Latawiec et al. 2014, Müller-Hansen et al. 2019); (iii) the negative effects of confinement and feedlots on animal welfare and environment (Vale et al. 2019); (iv) the environmental trade-offs between intensified and extensive cattle production; ( $v$ ) increasing demand for water associated with a growing cattle herd and additional resources for feed in feedlot finishing (Lathuillière et al. 2019). Moreover, several practices behind SI can be capital intensive or require high use of resources and investment capacity, thus creating barriers and a possible divide between farmers, increasing leakage effects.

On the other hand, agroforestry, agrosilvopastoral and silvopastoral systems (Tab. 1) benefit from the functional and biological synergies of Soil-Plant-Animal-Atmosphere Metabolic Interactions (sensu Magdoff 2011) well reported in the large mosaic of agrosilvopastoral solutions (Carvalho et al. 2018). Loker (1994) proposed a model of a low external input agrosilvopastoral system for the tropics. This model includes well-adapted grass-legume pastures, rotational grazing and the management of natural forest regeneration. Hohnwald et al. (2015) tested this model in practice and found that it represents a promising and ecologically sustainable alternative for smallholders. De facto, the importance of diversified farming systems incorporating farmer preferences and knowledge are currently increasing (Marchetti et al. 2020). Amézquita et al. (2005), comparing different silvopastoral systems with native forest and degraded pasture, reported higher levels of SOC and concluded that they can constitute a viable economic alternative to farmers. Also, intensive silvopastoral systems, characterized by the high-density cultivation of fodder shrubs and trees combined with livestock grazing, are reported as successful alternatives for tropical countries (Murgueitio et al. 2013). This approach proposes a "natural intensification" strategy (Calle et al. 2012), contributing to de- construct the dichotomy between agricultural intensification and land sparing. The introduction of Leucaena leucocephala is referred as a useful practice (Chará et al. 2019). The inclusion of commercial timber species can constitute an interesting perspective for farmer income integration (Silva et al. 2018, Ansolin et al. 2020, Pizarro et al. 2020). The use of Eucalyptus spp. has a notable importance, mainly in recent papers referring to silvopastoral experimental practices in large properties (De Carvalho et al. 2019, Magalhães et al. 2019, Domiciano et al. 2020, Gomes et al. 2020). Often, the use of Eucalyptus is related to the limitation of GHG emission intensity of cattle production (Havlík et al. 2014, De Figueiredo et al. 2017, De Oliveira Silva et al. 2018, Landholm et al. 2019, Eri et al. 2020), one of the reported benefits of silvopastoral systems.

Regarding SP and their adoption, though, cattle ranchers in the Amazon region generally show scarce interest. This lack of interest can be explained by the so called "Amazonian cattle culture" (Hoelle 2014). Landowners choose to adopt more SP only when the marginal return of extensive ranching is lower than the intensifying one, and/or land becomes a scarce resource (Latawiec et al. 2014). Additionally, land speculation, which determines directly unproductive profit-seeking mechanisms, influences the low adoption of SP since the real objective is to maintain control over large areas while awaiting infrastructure development and higher land prices (Garrett et al. 2017, Sauer 2018). Other reasons that limit the adoption of SP include the lack of validation regarding economic viability (Oliveira et al. 2017), high implementation costs (Latawiec et al. 2017, Lerner et al. 2017, zu Ermgassen et al. 2018) - in a sector in which no-one is really willing to pay for improvements -, difficulties to access credits (Cortner et al. 2019) and lack of incentives from public policies (zu Ermgassen et al. 2018). However, the very limited adoption of sustainable agricultural practices is slowly changing, mainly because of the expected improvements in productivity and profitability, while the environmental concern is not a priority for cattle ranchers ( Latawiec et al. 2017).

With regard to SP in soybean production, the overview differs from the performed analysis about cattle ranching. In fact, we have found a limited number of papers (13\% - see Fig. 5) addressing sustainable soybean productive systems. Soybean is a large scale open-field crop, and this could explain the lower suitability in adopting integrated agriculture and/or agroforestry practices, perceived as small-scale practices. Consequently, some proposed options in this direction resulting from our review are: double-cropping systems (Hampf et al. 2020); planting of soybean in croplivestock integrated systems (Gil et al. 2016); and/or inclusion of tree species in integrated systems (Martorano et al. 2016).
These systems appear economically more sustainable (Dos Reis et al. 2019), can contribute to mitigate GHG emissions (Carvalho et al. 2014) and to increase soil carbon stocks (Soares et al. 2020). Nevertheless, their success largely depends on successfully applied good management practices and technical support, and are still far from a broad application (Gil et al. 2016, Oliveira et al. 2018). Furthermore, a reported factor of sustainability in soybean cultivation in the Amazon region is its establishment on previously cleared and/or abandoned pastures, addressing the potential restoration of degraded land. However, a strong side effect is the consequent displacement of cattle ranching to the forest frontier (Barona et al. 2010, Domingues \& Bermann 2012, Gollnow \& Lakes 2014, Maranhão et al. 2019, Picoli et al. 2020). In conclusion, as evidenced from the reviewed papers, it appears that the actual sustainability of soy refers essentially to public policies and supply chain initiatives that are supposed to reduce deforestation and mitigate soy negative impacts.

\section{Meta-analysis of the effects of SP on ES}

The first relevant finding of our metaanalysis was the low number of studies fitting the inclusion criteria, revealing a critical gap in the scientific knowledge of the use of SP in the Amazon. In a meta-analysis on the effects of agroforestry systems on biodiversity and ES in Europe (Torralba et al. 2016), 53 studies were assessed, but with a clear geographical concentration, indicating that also in Europe there is an overall lack of empirical information.

Despite the relative low number of studies, the performed meta-analysis indicates that SP promoted an increase in four on six ESs as compared to conventional cropland and pastures and only woody biomass was lower as compared to natural vegetation. In the SP1 dataset, the two services that were negatively affected were crop yield and herbage biomass. Crop yield was negatively affected in all SP, and was responsible for the negative coefficient of the overall model. Such negative effect could be attributable to the shading effect of trees, and it was much higher in the corn crop (a $C_{4}$ plant) than in soybeans (a $C_{3}$ plant), the latter being significant only after the fourth year of SP implementation (Magalhães et al. 2019). The negative effects of SP on herbage biomass were somehow expected due to two major reasons: firstly, this variable was not measured in the pasture improvement studies; furthermore, as for crop yield, shading is known to reduce the productivity of grasses ( $C_{4}$ plants). However, studies indicating a negative effect on herbage biomass detected a positive and significant effect on livestock productivity. This result suggests that herbage biomass is not always a good predictor, as for example the thermal comfort (shade) provided by trees, or food production provided by woody species, may be relevant 
for livestock productivity (Junior et al. 2019). A similar trend was found in the European meta-analysis, with a negative relationship detected for biomass production, while food production was positively affected by agroforestry (Torralba et al. 2016).

Soil organic carbon (SOC) was higher in all SP as compared to conventional cropland and pastures. In the silvopasture systems, the presence of trees directly improve the carbon translocation from the sub-soil, both as foliage decay and as deposition of woody material (e.g., branches). Additionally, trees increase soil humidity and protection from erosion, as well as enhance the abundance and diversity of soil organisms (fungi, bacteria, micro-arthropods), facilitate decomposition and, consequently, carbon accumulation (Cruz et al. 2019, Petter et al. 2017). Crop rotation and pasture improvement also enhanced the SOC content, indicating that even in the absence of trees these practices are beneficial for soil quality (Mosquera et al. 2012). In accordance with our findings, a metaanalysis of the effects of agroforestry on SOC stocks found positive effects for agroforestry systems in relation to conventional croplands, pasturelands and uncultivated areas in various soil horizons and depths (De Stefano \& Jacobson 2018). Nevertheless, these authors found that the conversion of forests to agroforestry decreased SOC amount, while in our case there was a positive, though non-significant, relationship. Such a result was an outcome of the comparison against pasture improvement systems, once well managed pasturelands are known to present high levels of SOC, although a relevant fraction was accumulated by the pre-existing forest before the pasture establishment (Mosquera et al. 2012, Rittl et al. 2017).

Soil fertility was positively affected by crop rotation, agrosilvicultural and silvopastoral practices in both $\mathrm{SP}_{1}$ and $\mathrm{SP}_{2}$ datasets. Due to a higher input of organic matter and a higher protection against environmental agents (rain, wind, sunlight), such practices enhance the accumulation and transformation of most nutrients (Hohnwald et al. 2015, Silva et al. 2018). The improvement of soil fertility and nutrient cycling in agroforestry systems has also been observed in Europe (Torralba et al. 2016). In addition to the chemical components (nitrogen, phosphorous and sodium), our results indicated that SP practices also enhanced soil microbial and macro fauna abundance and diversity, a very important though often overlooked indicator of soil fertility (Barros et al. 2003, Cruz et al. 2019). Additionally, SP practices also reduced the potential of nitrification, a critical process in many agricultural fields (Cubillos et al. 2016).

As expected, woody biomass was higher in the silvopastoral and agrosilvopastoral systems evaluated. Besides producing important ES and improving biodiversity, woody biomass is an important source of income diversification (Ansolin et al. 2020, Domiciano et al. 2020, Silva \& Schwartz 2019), counterbalancing the reduction of crop yield and herbage biomass found in our results, although such direct comparisons are surprisingly poorly quantified in the literature (Torralba et al. 2016).

\section{Limitations of the meta-analysis}

For a correct interpretation of our results, some considerations must be taken into account. The first limitation of our meta-analysis is the reduced number of studies meeting the selection criteria (only 13 out of 144). The studies were discarded because they lack primary quantitative data, comparisons against a reference system or required information (means, standard deviations and sample sizes), strongly reducing the spectrum of ES provided by SP in the Amazon. Such narrow filtering, however, is a common issue in meta-analysis, particularly those targeting complex agricultural practices such as agroforestry and variables related to ES or biodiversity (Plieninger et al. 2014, Torralba et al. 2016, De Stefano \& Jacobson 2018). Another constraint for interpretation is the lack of standardization of the sampling protocols, as well as the high heterogeneity of the variables assessed, as mentioned in other meta-analysis (De Stefano \& Jacobson 2018).

\section{Public policies and supply chain} initiatives

The promotion of public policies, civil society actions and/or private arrangements on the meat and soy supply chain result as strategic assessments to mitigate the cattle and soybean sector's negative impacts and to foster their sustainability. These initiatives include, on one side, government conservation interventions, such as incentive-based regulations, establishment of protected areas and expansion of indigenous lands, land regulations, and police operations against environmental crimes (Müller et al. 2013, Le Polain De Waroux et al. 2019, Picoli et al. 2020). On the other hand, interventions in the supply chain include the non-state market-driven governance systems (Buckley et al. 2019), that should consider compulsory public-driven initiatives, policies and regulations and combine private sector, civil society and government interventions. They include roundtables, steering councils, zero deforestation agreements and other multi-stakeholder initiatives based on voluntary certification and market exclusion mechanisms, to create sustainable production standards (De Souza et al. 2017).

With regards to cattle ranching, the TAA "certification policies" and "supply chain initiatives" were addressed by $26 \%$ of the papers reviewed (Fig. 2). Early measures to combat deforestation determined by cattle ranching (started in the early 2000s) were represented by public policies, primarily based on command-and-control instru- ments. Later on, pressure on the main meat distribution chains has increased, and this has determined the implementation of different initiatives. Representative examples, in the case of Brazil, are the TAC (literally: Term of Adjustment of Conduct) and the "zero-deforestation agreement", signed in 2009. In both cases, meatpacking companies have committed to block acquisition from farms performing any deforestation after the agreement date (Gibbs et al. 2016, Guéneau 2018). Furthermore, the Brazilian Roundtable on Sustainable Livestock (GTPS), activated in 2009, based on a system of multi-stakeholder governance and claiming for a global/local large partnership, declares the commitment to zero deforestation, with the creation of the conditions and forms of compensation to make it viable (De Souza et al. 2017). The stated goal of GTPS is to drive the transition towards the sustainability of the sector, thanks to certification standards, verifying that producers comply with established criteria and supporting firms to purchase certified products (Buckley et al. 2019). A reported limit of these approaches is that they are hardly able to be widely applied, and generally they include only largescale farmers/companies (Silva \& Lima 2018), reinforcing the cattle (and soybean) typical "productive exclusion" of small farmers (McKay \& Colque 2015). In fact, large farmers connected to global agribusiness are considered key players due to their scale of production; while in contrast, diversified systems of family farmers could have greater potential for sustainable development (Medina \& Dos Santos 2017), but are hardly considered. Other limits reported are related to the fact that cattle are often raised on multiple properties prior to slaughter, fattened on noncompliant ranches, and then moved to a compliant property before sale to the slaughterhouses (so-called "laundering"), or even moved to regions not yet monitored by the agreements (so-called "leakage" - Gibbs et al. 2016, Brandão et al. 2020). This is mainly due to inadequate monitoring approaches and large segments of the cattle supply chain that are not tracked, meaning that such agreements do not necessarily translate into effective changes in sustainability (Buckley et al. 2019).

Regarding soybean, many specific efforts to control deforestation emerged from the government, the private sector and the civil society. These topics are addressed by $87 \%$ of the collected papers (Fig. 5). In fact, at the global level, there is a growing recognition and awareness of the remote environmental damages driven by global food consumption, which encouraged many private- and public-sector commitments to reduce impacts (Green et al. 2019). Besides the well-established effectiveness at reducing deforestation rates, the success of these interventions suffers numerous shortcomings. As an example, the Soy Moratorium, highly promoted in 
the last 15 years, represents the first large scale, voluntary zero-deforestation agreement created in collaboration between civil society, agribusiness industry and the Brazilian government, first signed in 2006 and extended to date. It is widely reported by the literature that, just after launching the moratorium, deforestation linked to soybean plantation in the Brazilian Amazon experienced a consistent decline (Rudorff et al. 2011, Nepstad et al. 2014, Azevedo et al. 2015, Gibbs et al. 2015, Kastens et al. 2017). Nevertheless, the reduction of direct pressure of soybean on the Amazon forest indirectly displaced other activities, mainly cattle ranching, impacting again on the forest frontier (Maranhão et al. 2019, Nepstad et al. 2019, Picoli et al. 2020). Furthermore, such reduction in the Amazon determined a displacement of soybean environmental pressure to other biomes, such as the Brazilian Cerrado (the current major soybean expansion frontier), concretely limiting the effectiveness of the moratorium (Dou et al. 2018, Gollnow et al. 2018, Rausch et al. 2019, zu Ermgassen et al. 2020). Finally, most of the actual soy production is not monitored by the moratorium, making monitoring and cross checking impossible (Lima et al. 2019). Soterroni et al. (2019) and Nepstad et al. (2019) have proposed to expand the Soy Moratorium to the Brazilian Cerrado, taking into account that the Brazilian legislation is much less restrictive in terms of permitted clearings in this biome, compared to the norms applied in the Amazon. Another example of multistakeholder voluntary governance mechanism is the Roundtable on Responsible Soy, which creates certification standards to verify that producers comply with established criteria and to support firms purchasing certified products. Nevertheless, its actual extremely low adoption rate and the small area of application compared to global soy area is a limitation to its effectiveness (Garrett et al. 2016). Furthermore, the soybean supply chain suffers from limited traceability. Leakage and laundering, processes through which soy grown on recently deforested area is included into the supply chain using tangled loopholes (Silva \& Lima 2018, zu Ermgassen et al. 2020), and noncompliance with legal requirements have been detected in properties that were "respecting" the moratorium criterion (Azevedo et al. 2015).

\section{Conclusions}

The results of the present review highlights a wide concern around the impacts of soybean crops and cattle ranching on the expansion of the agricultural frontier in the Amazon rainforest. The implementation of SP in their production chains is crucial. Nevertheless, research activities on indicators quantifying the benefits of applying SP need to be implemented, as highlighted by the meta-analysis. For example, despite the importance of crops in the Amazon region, also as deforestation driv- ers, crop-yield comparisons were found in only one study. This fact represents a very considerable gap and reflects a critical research weakness.

As a general conclusion, we should state that most of the papers are based on process- and discourses-oriented analysis more than deepening the robustness of claimed solutions. They draw a vivid picture of problems and statements, driving to governance approaches, but data on the effectiveness of SP, their comparability and replicability in research programs, are still very poor.

Nevertheless, some possible solutions stand out from our analysis. Regarding cattle ranching, it should be necessary to improve: the study and implementation of best practices; the incentive for increased productivity through technical assistance; and the decentralization of livestock keeping, instead of reinforcing the current trend toward larger landless livestock holdings. However, with regards to soybean cultivation, it seems that limited sustainable solutions, both for practices and policies, are available.

There remains an open question about how cattle ranching and soybean cultivation in the Amazon will become environmentally and socially sustainable in the long term. First of all, forests should no longer be reconverted to agricultural use. The reduction of soybean and cattle farming in the Amazon and the application of SP to increase efficiency and production of already existing productions appears to be crucial. The restoration and ecological improvement of degraded pastures, the use of agroforestry and silvopastoral systems should be supported, rather than industrial SI, whose numerous shortcomings have been demonstrated.

Profound changes in consumer behavior and diet are crucial, too: global reduction of meat consumption; fostering of food traceability; inclusion of the environmental costs of agricultural production in the price of food, to build a growing awareness among consumers; eating quality, not quantity. A comprehensive approach to achieving sustainability through a combination of solutions should be performed, to achieve social, economic and environmental objectives. In fact, the current focuses tend to ignore the negative externalities with respect to biodiversity conservation, social equality, land rights and climate change.

Furthermore, the pressure of deforestation in the Amazon might stimulate policies and their assessment should take into account the increasing coupling between production sectors and geographic locations and, at the same time, must be thoroughly grounded in an understanding of the region's agriculture and social processes, including the land tenure issue.

A possible input for further research should be the broadening of research focus to other biomes under risk caused by the two drivers investigated in this study. In Latin America, this may be the case for the Chaco, a cross-country area (Argentina, Brazil, Bolivia and Paraguay) seriously threatened by degradation dynamics, or for the Brazilian Cerrado, highly endangered by soybean and cattle ranching expansion.

\section{Acknowledgments}

We gratefully thank the two anonymous reviewers for the complete and grounded comments and suggestions, which were very helpful to better define concepts and improve the robustness of our research. We also thank Andy Speak for his contribution to the English language revision.

\section{References}

Amézquita $M C$, Ibrahim $M$, Llanderal $T$, Buurman $P$, Amézquita $E$ (2005). Carbon sequestration in pastures, silvopastoral systems and forests in four regions of the Latin American Tropics. Journal of Sustainable Forestry 21 (1): 31-49. doi: 10.1300/Jo91v21no1_02

Amigo I (2020). The Amazon's fragile future. Nature 578: 505-507. - doi: 10.1038/d41586-020-005 08-4

Ansolin RD, Timofeiczyk Junior R, Da Silva JCGL, Michetti M, Kamoi MYT, Dos Reis JC (2020). Strategic diagnosis of livestock-forest integration systems in Northern Mato Grosso. Floresta 50 (1): 1001-1010. - doi: 10.5380/rf.v50i1.60528 Armenteras D, Murcia U, González TM, Barón OJ, Arias JE (2019). Scenarios of land use and land cover change for NW Amazonia: impact on forest intactness. Global Ecology and Conservation 17: e00567. - doi: 10.1016/j.gecco.2019.e005 67

Azevedo AA, Stabile MCC, Reis TNP (2015). Commodity production in Brazil: combining zero deforestation and zero illegality. Elementa 3: 000076. - doi: 10.12952/journal.elementa.0000 76

Barona E, Ramankutty N, Hyman G, Coomes OT (2010). The role of pasture and soybean in deforestation of the Brazilian Amazon. Environmental Research Letters 5: 024002. - doi: 10.108 8/1748-9326/5/2/024002

Barros E, Neves A, Blanchart E, Fernandes ECM, Wandelli E, Lavelle P (2003). Development of the soil macrofauna community under silvopastoral and agrosilvicultural systems in Amazonia. Pedobiologia 47 (3): 273-280. - doi: 10.1078/00 31-4056-00190

Brandão A, Rausch L, Durán AP, Costa C, Spawn SA, Gibbs HK (2020). Estimating the potential for conservation and farming in the Amazon and Cerrado under four policy scenarios. Sustainability 12 (3): 1277. - doi: 10.3390/su12031277 Borges WLB, Calonego JC, Rosolem CA (2019). Impact of crop-livestock-forest integration on soil quality. Agroforestry Systems 93 (6): 21112119. - doi: 10.1007/s10457-018-0329-0

Buckley KJ, Newton P, Gibbs HK, McConnel I, Ehrmann J (2019). Pursuing sustainability through multi-stakeholder collaboration: a description of the governance, actions, and perceived impacts of the roundtables for sustainable beef. World Development 121: 203-217. - doi: 10.1016/j. worlddev.2018.07.019 
Calle Z, Murgueitio E, Chará J (2012). Integrating forestry, sustainable cattle-ranching and landscape restoration. Unasylva 63 (239): 31-40. [online] URL: http://www.researchgate.net/ publication/286762052

Carvalho JLN, Raucci GS, Frazão LA, Cerri CEP, Bernoux M, Cerri CC (2014). Crop-pasture rotation: a strategy to reduce soil greenhouse gas emissions in the Brazilian Cerrado. Agriculture, Ecosystem and Environment 183: 167-175. - doi: 10.1016/j.agee.2013.11.014

Carvalho PCF, Peterson CA, De Albuquerque Nunes PA, Martins AP, De Souza Filho W, Bertolazi VT, Kunrath TR, De Moraes A, Anghinoni I (2018). Animal production and soil characteristics from integrated crop-livestock systems: toward sustainable intensification. Journal of Animal Science 96 (8): 3513-3525. - doi: 10.1093/jas/ skyo85

Carvalho R, De Aguiar APD, Amaral S (2020). Diversity of cattle raising systems and its effects over forest regrowth in a core region of cattle production in the Brazilian Amazon. Regional Environmental Change 20 (2): 1821. - doi: 10.100 7/s10113-020-01626-5

Celidonio OLM, Werner LS, Gil JDB (2019). The determinants of recent soybean expansion in Mato Grosso, Brazil. International Food and Agribusiness Management Review 22 (2): 173191. - doi: 10.22434/IFAMR2018.0072

Cerri CC, Melillo JM, Feigl BJ, Piccolo MC, Neill C, Steudler PA, Carvalho MCS, Godinho VP, Cerri CEP, Bernoux M (2005). Recent history of the agriculture of the Brazilian Amazon Basin: prospects for sustainable development and a first look at the biogeochemical consequences of pasture reformation. Outlook on Agriculture 34 (4): 215-223. - doi: $10.5367 / 000000005775454$ 670

Chará J, Rivera J, Barahona R, Murgueitio E, Calle Z, Giraldo C (2019). Intensive silvopastoral systems with Leucaena leucocephala in Latin America. Tropical Grasslands - Forrajes Tropicales 7 (4): 259-266. - doi: 10.17138/tgft(7)259-266 Chung MG, Kapsar K, Frank KA, Liu J (2020). The spatial and temporal dynamics of global meat trade networks. Scientific Reports 10: 16657. doi: 10.1038/s41598-020-73591-2

Cortner O, Garrett RD, Valentim JF, Ferreira J, Niles MT, Reis J, Gil J (2019). Perceptions of integrated crop-livestock systems for sustainable intensification in the Brazilian Amazon. Land Use Policy 82: 841-853. - doi: 10.1016/j.landuse pol.2019.01.006

Cruz LG, Bastidas ATC, Suárez LR, Salazar JCS (2019). Microbial properties of soil in different coverages in the Colombian Amazon. Floresta e Ambiente 26 (4): 33. - doi: 10.1590/2179-8087. 105117

Cubillos AM, Vallejo VE, Arbeli Z, Terán W, Dick RP, Molina CH, Molina E, Roldan F (2016). Effect of the conversion of conventional pasture to intensive silvopastoral systems on edaphic bacterial and ammonia oxidizer communities in Colombia. European Journal of Soil Biology 72: 4250. - doi: 10.1016/j.ejsobi.2015.12.003

DeFries RS, Rudel T, Uriarte M, Hansen M (2010). Deforestation driven by urban population growth and agricultural trade in the twentyfirst century. Nature Geoscience 3: 178-181. doi: $10.1038 /$ ngeo756
De Carvalho P, Domiciano LF, Mombach MA, Do Nascimento HL, Da Silva Cabral L, Sollenberger LE, Pereira DH, Pedreira BC (2019). Forage and animal production on palisadegrass pastures growing in monoculture or as a component of integrated crop-livestock-forestry systems. Grass and Forage Science 74 (4): 650-660. - doi: 10.1111/gfs.v74.4

De Figueiredo EB, Jayasundara S, Bardonal RO, Berchielli TT, Reis RA, Wagner-Riddle C, La Scala NJ (2017). Greenhouse gas balance and carbon footprint of beef cattle in three contrasting pasture-management systems in Brazil. Journal of Cleaner Production 142: 420-431. doi: 10.1016/j.jclepro.2016.03.132

De Oliveira Resende L, Müller MD, Kohmann MM, Pinto LFG, Cullen Jr L, De Zen S, Rego LFG (2019). Silvopastoral management of beef cattle production for neutralizing the environmental impact of enteric methane emission. Agroforestry Systems 94: 893-903. - doi: 10.1007/s1 0457-019-00460-x

De Oliveira Silva R, Barioni LG, Pellegrino GQ, Moran D (2018). The role of agricultural intensification in Brazil's nationally determined contribution on emissions mitigation. Agricultural Systems 161: 102-112. - doi: 10.1016/j.agsy.2018. 01.003

De Souza DM, Petre R, Jackson F, Hadarits $M$, Pogue S, Carlyle CN, Bork E, McAllister T (2017). $A$ review of sustainability enhancements in the beef value chain: state-of-the-art and recommendations for future improvements. Animals 7 (12): 26. - doi: 10.3390/ani7030026

De Stefano A, Jacobson MG (2018). Soil carbon sequestration in agroforestry systems: a metaanalysis. Agroforestry Systems 92: 285-299. doi: 10.1007/s10457-017-0147-9

Dias-Filho MB (2015). Estratégias de recuperação de pastagens degradadas na Amazônia brasileira [Strategies for degraded pastures recuperation in the Brazilan Amazon]. Embrapa Amazônia Oriental, Belém, Brazil, pp. 12-13. [in Portuguese]

Dobson AP, Pimm SL, Hannah L, Kaufman L, Ahumada JA, Ando AW, Bernstein A, Busch J, Daszak P, Engelmann J, Kinnaird MF, Li BV, Loch-Temzelides T, Lovejoy T, Nowak K, Roehrdanz PR, Vale MM (2020). Ecology and economics for pandemic prevention. Science 369 (6502): 379-381. - doi: 10.1126/science.abc3189

Domiciano LF, Pedreira BC, Da Silva NMF, Mombach MA, Chizzotti FHM, Batista ED, Carvalho P, Cabral LS, Pereira DH, Do Nascimento HLB (2020). Agroforestry systems: an alternative to intensify forage-based livestock in the Brazilian Amazon. Agroforestry Systems 94: 1839-1849. doi: 10.1007/s10457-020-00499-1

Domingues MS, Bermann C (2012). O arco de desflorestamento na Amazônia: da pecuária à soja. [The arc of deforestation in the Amazon: from livestock to soybean]. Ambiente e Sociedade 15 (2): 1-22. [in Portuguese] - doi: 10.1590/ S1414-753X2012000200002

Dos Reis JC, Kamoi MYT, Latorraca D, Chen RFF, Michetti M, Wruck FJ, Garrett RD, Valentim JF, Rodrigues RAR, Rodrigues-Filho S (2019). Assessing the economic viability of integrated crop-livestock systems in Mato Grosso, Brazil. Renewable Agriculture and Food Systems 35 (6): 631-642. - doi: 10.1017/S1742170519000280
Dou Y, Da Silva RFB, Hongbo Y, Jianguo L (2018). Spillover effect offsets the conservation effort in the Amazon. Journal of Geographical Sciences 28 (11): 1715-1732. - doi: 10.1007/s11442-01 8-1539-0

Dubeux-Junior JCB, Muir JP, Apolinário VXO, Nair PKR, Lira MA, Sollenberger LE (2017). Tree legumes: an underexploited resource in warmclimate silvopastures. Revista Brasileira de Zootecnia 46 (8): 689-703. - doi: 10.1590/s1806-929 02017000800010

Eri M, Da Silva Jr CA, Lima M, La Scala Jr N, De Oliveira-Júnior JF, Teodoro PE, Capristo-Silva GF, Caione G, Peres CA (2020). Capitalizing on opportunities provided by pasture sudden death to enhance livestock sustainable management in Brazilian Amazonia. Environmental Development 33 (6): 100499. - doi: 10.1016/j.env dev.2020.100499

FAO/CIFOR (2019). Framework methodology for climate change vulnerability assessments of forests and forest dependent people. FAO, Rome, Italy, pp. 22-23.

FAO/UNEP (2020). The State of World's Forests 2020. Forests, biodiversity and people. FAO, Rome, Italy, pp. 82-88.

Fearnside PM (2001). Soybean cultivation as a threat to the environment in Brazil. Environmental Conservation 28 (1): 23-28. - doi: 10.1017/ S0376892901000030

Galimberti A, Cena H, Campone L, Ferri E, Dell'Agli $M$, Sangiovanni E, Belingheri $M$, Riva MA, Casiraghi M, Labra M (2020). Rethinking urban and food policies to improve citizens safety af ter COVID-19 pandemic. Frontiers in Nutrition 7: 569542. - doi: 10.3389/fnut.2020.569542

Garrett RD, Carlson KM, Rueda X, Noojipady P (2016). Assessing the potential additionality of certification by the roundtable on responsible soybeans and the roundtable on sustainable palm oil. Environmental Research Letters 11 (4): 045003. - doi: 10.1088/1748-9326/11/4/045003

Garrett RD, Gardner TA, Morello TF, Marchand S, Barlow J, De Blas DE, Ferreira J, Lees AC, Parry $L$ (2017). Explaining the persistence of low income and environmentally degrading land uses in the Brazilian Amazon. Ecology and Society 22 (3): 27. - doi: 10.5751/ES-09364-220327

Gibbs HK, Rausch L, Munger J, Schelly I, Morton DC, Noojipady P, Soares-Filho B, Barreto P, Micol L, Walker NF (2015). Brazil's Soy Moratorium: supply-chain governance is needed to avoid deforestation. Science 347 (6220): 377378. - doi: 10.1126/science.aaa0181

Gibbs HK, Munger J, L'Roe J, Barreto P, Pereira R, Christie M, Amaral T, Walker NF (2016). Did ranchers and slaughterhouses respond to zerodeforestation agreements in the Brazilian Amazon? Conservation Letters 9 (1): 32-42. - doi: 10.1111/conl.12175

Gil J, Siebold M, Berger T (2015). Adoption and development of integrated crop-livestock-forestry systems in Mato Grosso, Brazil. Agriculture, Ecosystem and Environment 199: 394406. - doi: 10.1016/j.agee.2014.10.008

Gil JDB, Garrett R, Berger T (2016). Determinants of crop-livestock integration in Brazil: evidence from the household and regional levels. Land Use Policy 59: 557-568. - doi: 10.1016/j.landuse pol.2016.09.022

Gil JDB, Garrett RD, Rotz A, Daioglou V, Valentim 
J, Pires GF, Costa MH, Lopes L, Reis JC (2018). Tradeoffs in the quest for climate smart agricultural intensification in Mato Grosso, Brazil. Environmental Research Letters 13 (6): 064025. doi: $10.1088 / 1748-9326 /$ aac4d1

Gollnow F, Lakes T (2014). Policy change, land use, and agriculture: the case of soy production and cattle ranching in Brazil, 2001-2012. Applied Geography 55: 203-211. - doi: 10.1016/j.apgeog. 2014.09.003

Gollnow F, De Barros Viana Hissa L, Rufin P, Lakes T (2018). Property-level direct and indirect deforestation for soybean production in the Amazon region of Mato Grosso, Brazil. Land Use Policy 78: 377-385. - doi: 10.1016/j. landusepol.2018.07.010

Gomes FJ, Pedreira BC, Santos PM, Bosi C, Lulu J, Pedreira CGS (2020). Microclimate effects on canopy characteristics of shaded palisadegrass pastures in a silvopastoral system in the Amazon biome of central Brazil. European Journal of Agronomy 115: 126029. - doi: 10.1016/j.eja.20 20.126029

Green JMH, Croft SA, Durán AP, Balmford AP, Burgess ND, Fick S, Gardner TA, Godar J, Suavet C, Virah-Sawmy M, Young LE, West CD (2019). Linking global drivers of agricultural trade to on-the-ground impacts on biodiversity. Proceedings of the National Academy of Sciences USA 116 (46): 23202-23208. - doi: 10.1073/pnas. 1905618116

Guéneau S (2018). Neoliberalism and the emergence of private sustainability initiatives: the case of the Brazilian cattle value chain. Business Strategy and the Environment 27 (2): 240251. - doi: 10.1002/bse.2013

Hampf AC, Stella T, Berg-Mohnicke M, Kawohl T, Kilian M, Nendel C (2020). Future yields of double-cropping systems in the Southern Amazon, Brazil, under climate change and technological development. Agricultural Systems 177 (3): 102707. - doi: 10.1016/j.agsy.2019.102707

Havlík P, Valin H, Herrero $M$, Obersteiner $M$, Schmid E, Rufino MC, Mosnier A, Thornton PK, Böttcher H, Conant RT, Frank S, Fritz S, Fuss S, Kraxner F, Notenbaert A (2014). Climate change mitigation through livestock system transitions. Proceedings of the National Academy of Sciences USA 111 (10): 3709-3714. - doi: 10.1073/pnas.1308044111

Henders S, Persson UM, Kastner T (2015). Trading forests: land-use change and carbon emissions embodied in production and exports of forest-risk commodities. Environmental Research Letters 10 (12): 125012. - doi: 10.1088/17 48-9326/10/12/125012

Hoelle J (2014). Cattle culture in the Brazilian Amazon. Human Organization 73 (4): 363-374. doi: 10.17730/humo.73.4.u61u675428341165 Hohnwald S, Rischkowsky B, Camarão AP, Schultze-Kraft R, Rodrigues Filho JA, King JM (2006). Integrating cattle into the slash-andburn cycle on smallholdings in the Eastern Amazon, using grass-capoeira or grass-legume pastures. Agriculture, Ecosystems and Environment 117 (4): 266-276. - doi: 10.1016/j.agee.20 06.04.014

Hohnwald S, Rischkowsky B, King JM, Camarão AP, Rodrigues Filho JA, Zeppenfeld T (2015). Intensive cattle browsing did not prevent fallow recuperation on smallholder grass-capoeira pastures in the NE-Amazon. Agroforestry Systems 89 (5): 813-828. - doi: 10.1007/s10457-0159815-9

Junior NAV, Silva MA, Caramori P, Nitsche P, Corrêa $K$, Alves D (2019). Temperature, thermal comfort, and animal ingestion behavior in a silvopastoral system. Semina: Ciencias Agrarias 40: 403-416. - doi: 10.5433/1679-0359.2019v4on $1 \mathrm{p} 403$

Kastens JH, Brown JC, Coutinho AC, Bishop CR, Esquerdo JCDM (2017). Soy moratorium impacts on soybean and deforestation dynamics in Mato Grosso, Brazil. PLoS One 12 (4): e0176168. - doi: 10.1371/journal.pone. 0176168

Kehoe L, Romero-Muñoz A, Polaina E, Estes L, Kreft H, Kuemmerle T (2017). Biodiversity at risk under future cropland expansion and intensification. Nature Ecology and Evolution 1 (8): 1129-1135. - doi: 10.1038/s41559-017-0234-3

Landholm DM, Pradhan P, Wegmann P, Romero Sánchez MA, Suárez Salazar JC, Kropp JP (2019). Reducing deforestation and improving livestock productivity: greenhouse gas mitigation potential of silvopastoral systems in Caquetá. Environmental Research Letters 14 (11): 114007. - doi: 10.1088/1748-9326/ab3db6

Latawiec AE, Strassburg BBN, Valentim JF, Ramos F, Alves-Pinto HN (2014). Intensification of cattle ranching production systems: socioeconomic and environmental synergies and risks in Brazil. Animal 8 (8): 1255-1263. - doi: 10.1017/ S1751731114001566

Latawiec AE, Strassburg BBN, Silva D, AlvesPinto HN, Feltran-Barbieri R, Castro A, Iribarrem $A$, Rangel MC, Kalif KAB, Gardner T, Beduschi F (2017). Improving land management in Brazil: a perspective from producers. Agriculture, Ecosystem and Environment 240: 276-286. - doi: 10.1016/j.agee.2017.01.043

Lathuillière MJ, Solvik K, Macedo MN, Graesser J, Miranda EJ, Couto EG, Johnson MS (2019). Cattle production in Southern Amazonia: implications for land and water management. Environmental Research Letters 14 (11): 114025. [online] URL: http://iopscience.iop.org/article/10.10 88/1748-9326/ab30a7/meta

Le Polain De Waroux Y, Garrett RD, Graesser J, Nolte C, White C, Lambin EF (2019). The restructuring of South American soy and beef production and trade under changing environmental regulations. World Development 121: 188-202. doi: 10.1016/j.worlddev.2017.05.034

Lerner AM, Rudel TK, Schneider LC, McGroddy M, Burbano DV, Mena CF (2015). The spontaneous emergence of silvopastoral landscapes in the Ecuadorian Amazon: patterns and processes. Regional Environmental Change 15 (7): 1421-1431. - doi: 10.1007/s10113-014-0699-4

Lerner AM, Zuluafa AF, Chará J, Etter A, Searchinger $T$ (2017). Sustainable cattle ranching in practice: moving from theory to planning in Colombia's livestock sector. Environmental Management 60 (2): 176-184. - doi: 10.1007/s002 67-017-0902-8

Lima M, Da Silva Jr CA, Rausch L, Gibbs HK, Johann JA (2019). Demystifying sustainable soy in Brazil. Land Use Policy 82: 349-352. - doi: 10.101 6/j.landusepol.2018.12.016

Loker WM (1994). Where's the beef? Incorporating cattle into sustainable agroforestry systems in the Amazon Basin. Agroforestry Systems 25
(3): 227-241. - doi: 10.1007/BFo0707462

Lovejoy TE, Nobre C (2019). Amazon tipping point: last chance for action. Science Advances 5: eaba2949. - doi: 10.1126/sciadv.aba2949

Magalhães CAS, Pedreira BC, Tonini H, Farias Neto AL (2019). Crop, livestock and forestry performance assessment under different production systems in the north of Mato Grosso, Brazil. Agroforestry Systems 93 (6): 2085-2096. - doi: 10.1007/s10457-018-0311-x

Magdoff F (2011). Ecological civilization. Monthly Review 62 (8): 1-25. - doi: 10.14452/MR-062-082011-01_1

Maranhã̃o RLA, De Carvalho Junior OA, Hermuche PM, Gomes RAT, Pimentel CMM, Guimarães RF (2019). The spatiotemporal dynamics of soybean and cattle production in Brazil. Sus tainability 11 (7): 2150. - doi: 10.3390/su11072150 Marchetti M (2005). Sulla questione della distruzione delle foreste tropicali, riflessioni dopo un viaggio nell'Amazzonia brasiliana [About tropical forests destruction, considerations after a journey in the Brazilian Amazon]. In: “Foreste Ricerca Cultura" (Corona P, lovino F, Maetzke F, Marchetti M, Menguzzato G, Nocentini S, Portoghesi L eds). Coppini Editore, Accademia Italiana di Scienze Forestali, Firenze, Itay, pp. 361-380.

Marchetti L, Cattivelli V, Cocozza C, Salbitano F, Marchetti M (2020). Beyond sustainability in food systems: perspectives from agroecology and social innovation. Sustainability 12 (18): 7524. - doi: $10.3390 /$ su12187524

Marengo JA (2006). On the hydrological cycle of the Amazon basin: a historical review and current state-of-the-art. Revista Brasileira de Meteorologia 21 (3): 1-19. [online] URL: http://clivar. org/sites/default/files/documents/vamos/LBAoo 2-2006_JAMarengo.pdf

Martorano LG, Siviero MA, Tourne DCM, Vieira SB, Fitzjarrald DR, Vettorazzi CA, Brienza Jr S, Yeared JAG, Meyering E, Lisboa LSS (2016). Agriculture and forest: a sustainable strategy in the Brazilian Amazon. Australian Journal of Crop Science 10 (8): 1136-1143. - doi: 10.21475/aj cs.2016.10.08.p7727

McKay B, Colque G (2015). Bolivia's soy complex: the development of "productive exclusion". The Journal of Peasant Studies 43 (2): 583-610. doi: 10.1080/03066150.2015.1053875

MEA (2005). Ecosystems and human well-being. A framework for assessment. Millennium Ecosystem Assessment, Island Press, Washington, DC, USA, pp. 53-60.

Medina G, Dos Santos AP (2017). Curbing enthusiasm for Brazilian agribusiness: the use of actor-specific assessments to transform sustainable development on the ground. Applied Geography 85: 101-112. - doi: 10.1016/j.apgeog.2017. 06.003

Montagnini F (2008). Management for sustainability and restoration of degraded pastures in the neotropics. In: "Post-Agricultural Succession in the Neotropics". Springer, New York, USA, pp. 265-295. - doi: 10.1007/978-0-387-336 42-8_13

Montagnini F, Ibrahim M, Murgueitio Restrepo E (2013). Silvopastoral systems and climate change mitigation in Latin America. Bois et Forets des Tropiques 67 (316): 3-16. - doi: 10.191 82/bft2013.316.a20528 
Moreira GM, Lima Neves JC, Magalhães CAS, De Farias Neto AL, Sauer G, Silva JFV, Fernandes RBA (2018). Soil chemical attributes in response to tree distance and sun-exposed faces after the implantation of an integrated crop-livestock-forestry system. Revista Árvore 42 (4): 317. - doi: 10.1590/1806-90882018000400005

Mosquera O, Buurman P, Ramirez BL, Amezquita MC (2012). Carbon stocks and dynamics under improved tropical pasture and silvopastoral systems in Colombian Amazonia. Geoderma 189-190 (4): 81-86. - doi: 10.1016/j.geoderma.20 12.04.022

Müller R, Pistorius T, Rohde S, Gerold G, Pacheco $P$ (2013). Policy options to reduce deforestation based on a systematic analysis of drivers and agents in lowland Bolivia. Land Use Policy 30 (1): 895-907. - doi: 10.1016/j.landusepol.2012.06. 019

Müller-Hansen F, Heitzig J, Donges JF, Cardoso MF, Dalla-Nora EL, Andrade P, Kurths J, Thonicke K (2019). Can intensification of cattle ranching reduce deforestation in the Amazon? Insights from an agent-based social-ecological model. Ecological Economics 159: 198-211. - doi: 10.1016/j.ecolecon.2018.12.025

Murgueitio E, Calle Z, Uribe F, Calle A, Solorio B (2011). Native trees and shrubs for the productive rehabilitation of tropical cattle ranching lands. Forest Ecology and Management 261 (10): 1654-1663. - doi: 10.1016/j.foreco.2010.09. 027

Murgueitio E, Chará JD, Solarte AJ, Uribe F, Zapata C, Rivera JE (2013). Agroforestería pecuaria y sistemas silvopastoriles intensivos (SSPi) para la adaptación ganadera al cambio climático con sostenibilidad [Livestock agroforestry and intensive silvopastoral systems (SSPi) for sustainable livestock adaptation to climate change]. Revista Colombiana de Ciencias Pecuarias 26: 313-316. [in Portuguese]

Nepstad D, McGrath D, Stickler C, Alencar A, Azevedo A, Swette B, Bezerra T, DiGiano M, Shimada J (2014). Slowing Amazon deforestation through public policy and interventions in beef and soy supply chains. Science 344 (6188): 1118-1123. - doi: 10.1126/science.1248525

Nepstad LS, Gerber JS, Hill JD, Dias LCP, Costa $\mathrm{MH}$, West PC (2019). Pathways for recent Cerrado soybean expansion: extending the soy moratorium and implementing integrated crop livestock systems with soybeans. Environmental Research Letters 14 (4): 044029. - doi: 10.1088/1748-9326/aafb85

Oliveira BS, De Carvalho MAC, Lange A, Wruck FJ, Dallacort R, Da Silva VP, Barea M (2017). Atributos físicos do solo em sistema de integração lavoura-pecuária-floresta, na região Amazônica. [Soil physical attributes in crop-livestock-forest integration in the Amazon region]. Espacios 38 (41): 8. [in Portuguese] [online] URL: http://www.researchgate.net/publication/ 319528726

Oliveira JM, Madari BE, Carvalho MTM, Assis PCR, Silveira RS, Lima ML, Wruck FJ, Medeiros JC, Machado PLOA (2018). Integrated farming systems for improving soil carbon balance in the southern Amazon of Brazil. Regional Environmental Change 18 (1): 105-116. - doi: 10.1007/ s10113-017-1146-0

Pedrosa LM, Hoshide AK, De Abreu DC, Molossi
L, Couto EG (2019). Financial transition and costs of sustainable agricultural intensification practices on a beef cattle and crop farm in Brazil's Amazon. Renewable Agriculture and Food Systems 36 (1): 26-37. - doi: 10.1017/S1742 170519000413

Pettenella D, Masiero M (2020). Deforestation made in Italy. Le responsabilità delle imprese e dei consumatori italiani nella deforestazione dei paesi tropicali [Deforestation made in Italy. Enterprises' and Italian consumers' responsiblity for tropical deforestation]. ETIFOR Srl, Università di Padova, Padova, Italy. pp. 77-79. [in Italian] [online] URL: http://www.researchgate. net/publication/344668325

Petter FA, De Lima LB, De Morais LA, Tavanti RFR, Nunes ME, Freddi OS, Marimon Jr BH (2017). Carbon stocks in oxisols under agriculture and forest in the southern Amazon of Brazil. Geoderma Regional 11: 53-61. - doi: 10.1016/j. geodrs.2017.09.001

Picoli MCA, Rorato A, Leitão P, Camara G, Maciel A, Hostert P, Sanches IDA (2020). Impacts of public and private sector policies on soybean and pasture expansion in Mato Grosso-Brazil from 2001 to 2017. Land 9 (1): 20. - doi: 10.3390/ land9010020

Pizarro D, Vásquez H, Bernal W, Fuentes E, Alegre J, Castillo MS, Gómez C (2020). Assessment of silvopasture systems in the northern Peruvian Amazon. Agroforestry Systems 94 (1): 173183. - doi: 10.1007/s10457-019-00381-9

Plieninger T, Hui C, Gaertner M, Huntsinger L (2014). The impact of land abandonment on species richness and abundance in the Mediterranean Basin: a meta-analysis. PLoS One 9 (5): e98355. - doi: 10.1371/journal.pone.0098355 R Core Team (2019). R: a language and environment for statistical computing, version 3.6.1. $R$ Foundation for Statistical Computing, Vienna, Austria. [online] URL: http://www.r-project.org Rausch LL, Gibbs HK, Schelly I, Brandão Jr A, Morton DC, Carneiro Filho A, Strassburg B, Walker N, Noojipady Barreto P, Meyer D (2019). Soy expansion in Brazil's Cerrado. Conservation Letters 12 (6): e12671. - doi: 10.1111/conl.v12.6 Rittl TF, Oliveira D, Cerri CEP (2017). Soil carbon stock changes under different land uses in the Amazon. Geoderma Regional 10: 138-143. - doi: 10.1016/j.geodrs.2017.07.004

Rudorff BFT, Adami M, Aguiar DA, Moreira MA, Mello MP, Fabiani L, Amaral DF, Pires BM (2011). The soy moratorium in the Amazon biome monitored by remote sensing images. Remote Sensing 3 (1): 185-202. - doi: 10.3390/rs 3010185

Sauer S (2018). Soy expansion into the agricultural frontiers of the Brazilian Amazon: the agribusiness economy and its social and environmental conflicts. Land Use Policy 79: 326338. - doi: 10.1016/j.landusepol.2018.08.030 Schultze-Kraft R, Rao IM, Peters M, Clements RJ, Bai C, Liu G (2018). Tropical forage legumes for environmental benefits: an overview. Tropical Grasslands - Forrajes Tropicales 6 (1): 1-14. - doi: 10.17138/TGFT(6)1-14

Silva CA, Lima M (2018). Soy moratorium in Mato Grosso: deforestation undermines the agreement. Land Use Policy 71: 540-542. - doi: 10.101 6/j.landusepol.2017.11.011

Silva AR, Schwartz G (2019). Sobrevivência e cre- scimento inicial de espécies florestais em sistema de integração lavoura-pecuária-floresta no leste da Amazônia [Forest species survival and initial growth in crop-livestock-forest integration in the Eastern Amazon]. Revista em Agronegocio e Meio Ambiente 12 (1): 45-63. [in Portuguese ] - doi: 10.17765/2176-9168.2019v12n1 p45-63

Silva JCN, Silva AR, Veloso CAC, Dantas EF, Do Sacramento JAAS (2018). Aggregation, carbon, and total soil nitrogen in crop-livestock-forest integration in the Eastern Amazon. Revista Brasileira de Engenharia Agricola e Ambiental 22 (12): 837-842. - doi: 10.1590/1807-1929/agriambi. v22n12p837-842

Soares MB, Freddi OS, Matos ES, Tavanti RFR, Wruck FJ, De Lima JP, Marchioro V, Franchini JC (2020). Integrated production systems: an alternative to soil chemical quality restoration in the Cerrado-Amazon ecotone. Catena 185: 104279. - doi: 10.1016/j.catena.2019.104279

Soterroni AC, Ramos FM, Mosnier A, Fargione J, Andrade PR, Baumgarten L, Pirker J, Obersteiner M, Kraxner F, Câmara G, Carvalho AXY, Polasky S (2019). Expanding the soy moratorium to Brazil's Cerrado. Science Advances 5 (7): eaav7336. - doi: 10.1126/sciadv.aav7336

Strassburg BBN, Latawiec AE, Barioni LG, Nobre CA, Da Silva VP, Valentim JF, Vianna M, Assad ED (2014). When enough should be enough: improving the use of current agricultural lands could meet production demands and spare natural habitats in Brazil. Global Environmental Change 28 (1): 84-97. - doi: 10.1016/j.gloenvcha. 2014.06.001

Sullivan MJ, Talbot J, Lewis SL, Phillips OL, Qie L, Begne SK, Chave J, Cuni-Sanchez A, Hubau W, Lopez-Gonzalez G, Miles L, Monteagudo-Mendoza A, Sonké B, Sunderland T, ter Steege $H$, White $\amalg$, Affum-Baffoe K, Aiba Si, de Almeida EC, de Oliveira EA, Alvarez-Loayza P, Dávila EÁ, Andrade A, Aragão LE, Ashton P, Aymard C. GA, Baker TR, Balinga M, Banin LF, Baraloto C, Bastin JF, Berry N, Bogaert J, Bonal D, Bongers F, Brienen R, Camargo JL, Cerón C, Moscoso VC, Chezeaux E, Clark CJ, Pacheco ÁC, Comiskey JA, Valverde FC, Coronado EN, Dargie G, Davies SJ, De Canniere C, Djuikouo K. MN, Doucet JL, Erwin TL, Espejo JS, Ewango CE, Fauset S, Feldpausch TR, Herrera R, Gilpin M, Gloor E, Hall JS, Harris DJ, Hart TB, Kartawinata K, Kho LK, Kitayama K, Laurance SG, Laurance WF, Leal ME, Lovejoy T, Lovett JC, Lukasu FM, Makana JR, Malhi Y, Maracahipes L, Marimon BS, Junior BH, Marshall AR, Morandi PS, Mukendi JT, Mukinzi J, Nilus R, Vargas PN, Camacho NC, Pardo G, Peña-Claros M, Pétronelli P, Pickavance GC, Poulsen AD, Poulsen JR, Primack RB, Priyadi $H$, Quesada CA, Reitsma J, Réjou-Méchain $M, R e-$ strepo Z, Rutishauser E, Salim KA, Salomão RP, Samsoedin I, Sheil D, Sierra R, Silveira M, Slik JW, Steel L, Taedoumg H, Tan S, Terborgh JW, Thomas SC, Toledo M, Umunay PM, Gamarra LV, Vieira IC, Vos VA, Wang O, Willcock S, Zemagho $L$ (2017). Diversity and carbon storage across the tropical forest biome. Scientific Reports 7 (1): 401. - doi: 10.1038/srep39102

Torralba M, Fagerholm N, Burgess PJ, Moreno G, Plieninger T (2016). Do European agroforestry systems enhance biodiversity and ecosystem services? A meta-analysis. Agriculture, Ecosys- 
tems and Environment 230: 150-161. - doi: 10.1016/j.agee.2016.06.002

Vale P, Gibbs H, Vale R, Christie M, Florence E, Munger J, Sabaini D (2019). The expansion of intensive beef farming to the Brazilian Amazon. Global Environmental Change 57 (6): 101922. doi: 10.1016/j.gloenvcha.2019.05.006

Valentine JC, Pigott TD, Rothstein HR (2010). How many studies do you need? A primer on statistical power for meta-analysis. Journal of Educational and Behavioral Statistics 35 (2) 215-247. - doi: 10.3102/1076998609346961

Voora V, Larrea C, Bermudez S (2020). Global market report: soybean. Sustainable Commodities Marketplace Series 2019, The International Institute for Sustainable Development - IISD, Winnipeg, Manitoba, Canada, pp. 20. [online] URL: http://www.iisd.org/system/files/2020-10/ ssi-global-market-report-soybean.pdf zu Ermgassen EKHJ, De Alcantara MP, Balmford A, Barioni L, Beduschi Neto F, Bettarello MMF, De Brito G, Carrero GC, Florence EAS, Garcia E, Gonçalves ET, Da Luz CS, Mallman GM, Strassburg BBN, Valentim JF, Latawiec A (2018). Results from on-the-ground efforts to promote sustainable cattle ranching in the Brazilian Amazon. Sustainability 10 (4): 1301. - doi: 10.3122 o/osf.io/axyjk

zu Ermgassen EK, Ayre B, Godar J, Bastos Lima MG, Bauch S, Garrett R, Green J, Lathuillière $M J$, Löfgren $P$, Macfarquhar C, Meyfroidt $P$, Suavet C, West C, Gardner T (2020). Using supply chain data to monitor zero deforestation commitments: an assessment of progress in the Brazilian soy sector. Environmental Research Letters 15 (3): 035003. - doi: 10.1088/174 8-9326/ab6497

\section{Supplementary Material}

Tab. S1 - References used in the meta-analysis, average annual precipitation and temperatures of the study sites and references that compared the results also against native forest.

Fig. S1 - Linear relationship between the effect sizes and annual average precipitation found in the 13 studies used in the meta-analysis.

Fig. S2 - Linear relationship between the effect sizes and annual average temperature found in the 13 studies used in the meta-analysis.

Link: Bueno_3779@supploo1.pdf 